\title{
Soil fertility, plant nutrition, and grain yield of upland rice affected by surface application of lime, silicate, and phosphogypsum in a tropical no-till system
}

\author{
Carlos A.C. Crusciol ${ }^{\mathrm{a}, *}$, Angela C.C.A. Artigiani ${ }^{\mathrm{a}}$, Orivaldo Arf $^{\mathrm{b}}$, Antonio C.A. Carmeis Filho ${ }^{\mathrm{a}}$, Rogério P. Soratto ${ }^{\mathrm{a}}$, \\ Adriano S. Nascente ${ }^{\mathrm{c}, 1}$, Rita C.F. Alvarez ${ }^{\mathrm{c}, 2}$ \\ a São Paulo State University (UNESP), College of Agricultural Sciences, Department of Crop Science, P.O. Box 237, 18610-307, Botucatu, State of São Paulo, Brazil \\ ${ }^{\mathrm{b}}$ UNESP, College of Engineering, Department of Crop Science, Food Technology, and Social Economy, P.O. Box 31, 15385-000, Ilha Solteira, State of São Paulo, Brazil \\ c UNESP, College of Agricultural Sciences, Botucatu, State of São Paulo, Brazil
}

\section{A R T I C L E I N F O}

Article history:

Received 2 March 2015

Received in revised form 15 September 2015

Accepted 15 September 2015

Available online 25 September 2015

\section{Keywords:}

Soil amendment

Cation mobility

Combined alkaline substances

Plant nutrition

Oryza sativa

\begin{abstract}
A B S T R A C T
The development of technologies that provide rapid acidity amelioration of the soil profile through the surface application of amendments and phosphogypsum, such as no-till (NT) systems, is extremely important to provide adequate chemical conditions in tropical soils with low natural fertility, which limits the grain yield of upland rice (Oryza sativa L.). Thus, this study aimed to evaluate the effects of surface applications of lime, silicate, and phosphogypsum, applied individually or in mixtures, on the chemical properties of the soil profile in an NT system and to determine their effects on the nutrition, yield components, and grain yield of upland rice. The experiment was designed as a completely randomized block with eight treatments replicated four times. The combination of phosphogypsum with lime and/or silicate improved the surface and subsurface soil chemical properties 12 months following application. The mixtures increased the concentrations of $\mathrm{K}, \mathrm{Ca}, \mathrm{Mg}, \mathrm{N}-\mathrm{NO}_{3}^{-}$, and $\mathrm{S}-\mathrm{SO}_{4}^{2-}$ in the subsurface layers. The sulphur concentration in the flag leaves of upland rice was higher with phosphogypsum application. The number of panicles per $\mathrm{m}^{2}$ and grain yield of upland rice were positively influenced by the surface application of soil acidity amendments and phosphogypsum mixtures.
\end{abstract}

(c) 2015 Elsevier B.V. All rights reserved.

\section{Introduction}

Rice (Oryza sativa L.) is an important component of the diets of approximately half of the world's population (Kumar and Ladha, 2011). This cereal is cultivated primarily in Asia under controlled flood irrigation (Farooq et al., 2009; Prasad, 2011); however, a reduction in hydric resource availability for crop irrigation, resulting from increased industrial and human consumption, has led to the search for alternative methods of rice cultivation with lower water demand (Feng et al., 2007; Qu et al., 2008). The use of soil conservation management systems for the cultivation of upland rice has been suggested as an excellent alternative to increase global rice production and to reduce water use in agriculture, especially for soils with low available water capacity (Bouman and Tuong, 2001; Nascente et al., 2013).

\footnotetext{
* Corresponding author.

E-mail address: crusciol@fca.unesp.br (C.A.C. Crusciol).

${ }^{1}$ Currently: Brazilian Agricultural Research Corporation (EMBRAPA), Rice and Bean Research Center, P.O. Box 179, 75375-000, Santo Antônio de Goiás, State of Goiás, Brazil.

2 Currently: Federal University of Mato Grosso do Sul (UFMS), P.O. Box 112, 79560-000, Chapadão do Sul, State of Mato Grosso do Sul, Brazil.
}

The benefits of no-till (NT) systems for improving soil water retention and crop yields have led to worldwide adoption (Gozubuyuk et al., 2014); NT systems are currently used over an area of approximately 157 million ha, distributed primarily in Latin America (66 million ha), the USA and Canada (36 million ha), and Australia (18 million ha) (FAO, 2015).

The continued success of NT systems has been achieved through soil fertility management (Soratto and Crusciol, 2008a). However, in several tropical regions, the benefits of these agricultural production systems are limited by soil acidity, which reduces the availability of macronutrients and results in problems associated with manganese and aluminium toxicity (Oliveira and Pavan, 1996; Caires et al., 2008b; Churka Blum et al., 2013). Limestone is a common material that is used to ameliorate soil acidity; however, due to the low solubility and mobility of carbonate in the soil profile, surface liming effects are usually limited to lime application/incorporation sites (Caires et al., 2005, 2006; Soratto and Crusciol, 2008b). Under these conditions, the development of the root system is limited to a small volume of soil in the superficial layers, which in turn negatively influences crop grain yield, mainly in regions with frequent dry spells (Caires et al., 2008a).

Among certain strategies used to ameliorate subsurface soil acidity is the replacement of lime by the surface application of more soluble 
materials (Castro and Crusciol, 2013). However, to be considered effective, these materials must contain oxides, hydroxides, or silicates as neutralizing constituents (Alcarde and Rodella, 2003). By-products such as steel industry slags (basically composed of Ca and Mg silicate) can be a good alternative to replace or increase the surface liming effect due to their higher solubility and alkalinity compared with lime, which can reduce the time associated with the liming reactions in the soil profile (Peregrina et al., 2008; Yi et al., 2012). In addition, Ca, Mg, and Si sources may be useful for crops, reducing lime consumption (Castro and Crusciol, 2013) and improving the performance of Si-accumulating crops (Liang et al., 1994; Korndörfer and Lepsch, 2001; Guntzer et al., 2011).

The surface application of soil acidity amendments (lime and silicate) with low solubility has restricted the yield potential of several crops as a result of high $\mathrm{Al}^{3+}$ levels and low availability of basic ions in the subsurface soil (Reeve and Sumner, 1972; Smith et al., 1994; Caires et al., 2011), which can reduce the downward movement of alkaline substances. The occurrence and reaction of free $\mathrm{Al}^{3+}$ species in water generates hydrogen ions in the soil solution (Lindsay, 1979), which results in high potential acidity $(\mathrm{H}+\mathrm{Al})$ levels. This effect supposedly increases the neutralizing constituents required to reduce the generated acidity.

By-products such as phosphogypsum reduce the concentration of free $\mathrm{Al}^{3+}$ in the soil solution (Sumner et al., 1986; Shainberg et al., 1989), especially in the subsurface soil layers (Sumner, 1993), which is favourable for the amelioration of soil profile acidity in a shorter time period. Supposedly, the phosphogypsum reaction can improve the time effects of soil acidity amendments (lime and silicate), which is related to the high solubility and mobility of Ca sulphate throughout the soil profile (Farina et al., 2000; Alcarde and Rodella, 2003). Each type of gypsum has specific chemical characteristics, but most of them are considered excellent sources of $\mathrm{Ca}^{2+}$ and $\mathrm{SO}_{4}^{2-}$ for subsurface soil layers, which allows greater development of deep roots in acidic soils, reducing water stress caused by drought periods (Sumner et al., 1986; Alva and Gascho, 1991; Rutherford et al., 1994; Soratto and Crusciol, 2008a; Soratto et al., 2010; Caires et al., 2011).

Although upland rice has been considered acid-tolerant, new cultivars with better genotypic performance are apparently less tolerant to high $\mathrm{Al}^{3+}$ toxicity and the poor chemical conditions of tropical soils (Fageria et al., 2015). In addition, some studies suggest that fertilizer application, including Si sources, significantly increases upland rice grain yield, which indicates greater nutrient demand (Seebold et al., 2000; Korndörfer and Lepsch, 2001; Crusciol et al., 2013). Therefore, the adoption of new techniques in acidic soils under NT systems is essential to provide better conditions for plant development, resulting in increases in upland rice production.

The identification of alternatives that enable the amelioration of soil acidity at depth in an NT system through surface application without the incorporation of amendments may facilitate the success and continued use of this type of agricultural system. In addition, there is limited information on the surface application of acidity amendments and phosphogypsum applied as a mixture to tropical soils, which may have potential to improve the reactions of substances with low mobility and solubility.

Thus, this study was based on the following hypotheses: a) the surface application of silicate can neutralize soil acidity and provide $\mathrm{Ca}$ at depth in a shorter time period compared with the application of lime only; b) the application of soil acidity amendments (silicate + lime) in a mixture is more efficient than individual applications of each amendment with respect to reducing the acidity of the soil profile; c) due to its high mobility, the addition of phosphogypsum to soil acidity amendments (silicate + lime) promotes the enrichment of bases in the soil profile in a shorter time period compared with individual or mixed applications of lime and silicate; and d) the application of soil acidity amendments mixed with phosphogypsum can increase the grain yield of upland rice.
In summary, the aims of this study were to evaluate the effects of superficially applied silicate, lime, and phosphogypsum mixtures on the amelioration of the soil profile under an NT system, and to determine their effects on the nutrition, yield components, and grain yield of upland rice crop.

\section{Materials and methods}

\subsection{Site description}

A field experiment was conducted in the Cerrado region, Selvíria, State of Mato Grosso do Sul, Brazil ( $51^{\circ} 22^{\prime}$ W, $20^{\circ} 22^{\prime}$ S, $335 \mathrm{~m}$ a.s.l.) over two growing seasons. The soil was classified as a clay-textured Typic Acrustox (USDA, 1999). The chemical properties of the soil were determined at multiple depths $(0-0.05,0.05-0.10,0.10-0.20$, and $0.20-0.40 \mathrm{~m}$ ) prior to installing the experiment (Table 1 ), according to the methodologies described by van Raij et al. (1986).

The long-term (1956-2006) mean temperature during the rice growing season was $26.9{ }^{\circ} \mathrm{C}$, with a minimum of $21.4^{\circ} \mathrm{C}$ and a maximum of $32.4{ }^{\circ} \mathrm{C}$. The mean rainfall during this period was $749 \mathrm{~mm}$. In addition, during the experimental period, the minimum and maximum air temperatures and rainfall were measured daily (Fig. 1).

\subsection{Experimental design and treatment establishment}

The experiment was designed as a randomized complete block with eight treatments and four replications. Each plot covered an area of $35 \mathrm{~m}^{2}(5.0 \mathrm{~m} \times 7.0 \mathrm{~m})$. The following treatments were tested: (i) control (no lime, silicate, or phosphogypsum); (ii) phosphogypsum (3.0 $\left.\mathrm{Mg} \mathrm{ha}^{-1}\right)$; (iii) lime (2.1 $\mathrm{Mg} \mathrm{ha}^{-1}$ ); (iv) silicate $\left(2.2 \mathrm{Mg} \mathrm{ha}^{-1}\right)$; (v) lime and silicate mix (1.05 $\left.\mathrm{Mg} \mathrm{ha}{ }^{-1}+1.1 \mathrm{Mg} \mathrm{ha}^{-1}\right)$; (vi) lime and phosphogypsum mix (2.1 $\left.\mathrm{Mg} \mathrm{ha}^{-1}+3.0 \mathrm{Mg} \mathrm{ha}^{-1}\right)$; (vii) silicate and phosphogypsum mix (2.1 Mg ha $\left.{ }^{-1}+3.0 \mathrm{Mg} \mathrm{ha}^{-1}\right)$; and (viii) lime, silicate, and phosphogypsum mix (1.05 $\mathrm{Mg} \mathrm{ha}^{-1}+$ 1.1 $\left.\mathrm{Mg} \mathrm{ha}^{-1}+3.0 \mathrm{Mg} \mathrm{ha}^{-1}\right)$.

The dolomitic limestone and Ca and Mg silicate rate ( $\mathrm{R}$ ) was calculated to increase the base saturation (BS) in the topsoil (0-0.20 $\mathrm{m}$ ) to $70 \%$, using Eq. (1) as described by Cantarella et al. (1998).

$\mathrm{R}\left(\mathrm{kg} \mathrm{ha}^{-1}\right)=\left(\mathrm{BS}_{2}-\mathrm{BS}_{1}\right) \mathrm{CEC} /(\mathrm{ECCE} / 100)$

where ECCE is the effective Ca carbonate equivalent of the amendments; $\mathrm{BS}_{2}$ is the estimated base saturation (70\%); and $\mathrm{BS}_{1}$ is the base saturation measured in the soil, calculated using Eq. (2) as described by Cantarella et al. (1998).

$\mathrm{BS}_{1}(\%)=\left(\mathrm{Ca}_{\mathrm{ex}}+\mathrm{Mg}_{\mathrm{ex}}+\mathrm{K}_{\mathrm{ex}}\right) 100 / \mathrm{CEC}$

where $\mathrm{Ca}_{\mathrm{ex}}, \mathrm{Mg}_{\mathrm{ex}}$, and $\mathrm{K}_{\mathrm{ex}}$ are basic exchangeable cations, and CEC is the total cation exchange capacity, which was calculated using Eq. (3).

$$
\begin{aligned}
\operatorname{CEC}\left(\mathrm{mmol}_{\mathrm{c}} \mathrm{dm}^{-3}\right)= & \mathrm{Ca}_{\mathrm{ex}}+\mathrm{Mg}_{\mathrm{ex}}+\mathrm{K}_{\mathrm{ex}} \\
& + \text { total acidity at } \mathrm{pH} 7.0(\mathrm{H}+\mathrm{Al})
\end{aligned}
$$

The phosphogypsum rate (GR) was calculated using Eq. (4), as recommended by van Raij et al. (1997).

$\mathrm{GR}\left(\mathrm{kg} \mathrm{ha}^{-1}\right)=6 \mathrm{CL}$ layer.

where $\mathrm{CL}$ is the clay content $\left(\mathrm{g} \mathrm{kg}^{-1}\right)$ in the 0.20 - to $0.40-\mathrm{m}$ soil

The dolomitic limestone was composed of $30 \% \mathrm{Ca}$ and $7.2 \% \mathrm{Mg}$ with an ECCE of $86 \%$. The Ca and Mg silicate, a by-product obtained from the steel manufacturing process, contained $23 \% \mathrm{SiO}_{2}, 26 \% \mathrm{Ca}$, and $7.8 \% \mathrm{Mg}$ with an ECCE of 82\%; minor amounts of heavy metals were detected, 
Table 1

Soil chemical properties of the experimental area prior to experiment initiation.

\begin{tabular}{|c|c|c|c|c|c|c|c|c|c|c|c|c|}
\hline \multirow{2}{*}{$\frac{\text { Depth }}{(\mathrm{cm})}$} & \multirow{2}{*}{$\mathrm{pH}\left(\mathrm{CaCl}_{2}\right)$} & \multirow{2}{*}{$\frac{\text { O.M. }^{\mathrm{a}}}{\left(\mathrm{g} \mathrm{dm}^{-3}\right)}$} & $\mathrm{P}$ (resin) & $\mathrm{S}-\mathrm{SO}_{4}^{2-}$ & $\mathrm{Si}$ & $\mathrm{Al}$ & $\mathrm{H}+\mathrm{Al}$ & $\mathrm{K}$ & $\mathrm{Ca}$ & $\mathrm{Mg}$ & CEC & \multirow{2}{*}{$\frac{\mathrm{V}}{(\%)}$} \\
\hline & & & \multicolumn{3}{|c|}{$\left(\mathrm{mg} \mathrm{dm}^{-3}\right)$} & \multicolumn{6}{|c|}{$\left(\mathrm{mmol}_{\mathrm{c}} \mathrm{dm}^{-3}\right)$} & \\
\hline $0-5$ & 4.9 & 28 & 22 & 14 & 6.2 & 1.2 & 40 & 3.3 & 18 & 14 & 75 & 47 \\
\hline $5-10$ & 4.8 & 25 & 28 & 14 & 5.4 & 2.1 & 40 & 0.7 & 16 & 10 & 67 & 40 \\
\hline $10-20$ & 4.9 & 26 & 16 & 16 & 5.7 & 1.1 & 37 & 0.6 & 18 & 13 & 69 & 46 \\
\hline $20-40$ & 4.7 & 23 & 8 & 40 & 4.7 & 3.0 & 34 & 0.6 & 12 & 9 & 56 & 39 \\
\hline $0-20$ & 4.9 & 27 & 20 & 16 & 5.9 & 1.1 & 40 & 1.5 & 19 & 12 & 73 & 45 \\
\hline
\end{tabular}

a O.M., organic matter.

i.e., $\mathrm{Cd}, \mathrm{Ni}, \mathrm{Pb}, \mathrm{Cr}$, and $\mathrm{Hg}$, at concentrations of 3.1, 53.6, 12.6, 990, and $<0.1 \mathrm{mg} \mathrm{kg}^{-1}$, respectively. These are not considered pollutants according to their trace element concentrations in biosolid material (USEPA, 1994). The phosphogypsum $\left(\mathrm{CaSO}_{4} \cdot 2 \mathrm{H}_{2} \mathrm{O}\right)$, which is a by-product obtained from a Brazilian phosphoric acid company, was composed of $22 \% \mathrm{Ca}, 17 \% \mathrm{~S}$, and residual $\mathrm{P}$ and $\mathrm{F}(0.1 \%)$.

The products were dried before being mixed. A mechanical mixer was used to produce the mixtures, and all mixtures and individual products were stored in packets. Fifteen days before product application, pearl millet was dried by applying glyphosate ( $1800 \mathrm{~g}$ active ingredient $\mathrm{ha}^{-1}$ ). The products were applied to millet straw without soil incorporation one month (October) before the upland rice was sown.

\subsection{Rice cultivar characteristics and crop management}

The rice cultivar BRS Primavera has a short life cycle (95-105 days), long grains and high drought tolerance. This cultivar was developed by the Rice and Bean National Research Center (EMBRAPA - Brazilian Agricultural Research Corporation) and has produced good results in several management systems (Santos et al., 2006).

Upland rice BRS Primavera cultivar seeds were planted in the fourth week of November in two growing seasons (2003-2004 and 20042005 ) at a spacing of $0.35 \mathrm{~m}$ between rows, with 80 seeds $\mathrm{m}^{-1}$ row. Base fertilization was performed using $300 \mathrm{~kg} \mathrm{ha}^{-1}$ of $\mathrm{N}-\mathrm{P}_{2} \mathrm{O}_{5}-\mathrm{K}_{\mathrm{O}}$ $(08-28-16)+0.4 \% \mathrm{Zn}$, and top dressing fertilization consisted of $60 \mathrm{~kg}$ of $\mathrm{N}$ (urea) ha ${ }^{-1}$ at the tillering stage, as recommended by Cantarella et al. (1997). In both growing seasons, there was homogeneous germination and no limitation of upland rice growth due to weeds or pests.

Water was not a limiting factor in the experiment because the upland rice received supplementary water when necessary. The soil matric potential was monitored inside the experimental area using 12 conventional mercury tensiometres (13-mm diameter, with a ceramic porous cup connected by tubing to a mercury manometer), which were constructed according to Richards (1941) and installed on the planting date at a depth of $0.15 \mathrm{~m}$. Irrigation was performed when the mean matric potential of the soil reached $-0.058 \mathrm{MPa}$ (vegetative and maturity phenological phases) or $-0.033 \mathrm{MPa}$ (reproductive phenological phase) according to recommendations by Stone et al. (1986), and was calculated to increase the soil moisture tension to field capacity.

\subsection{Soil sampling and chemical analyses}

Three and twelve months after treatment establishment, eight individual soil samples were randomly collected at depths of $0.00-0.05$, $0.05-0.10,0.10-0.20$ and $0.20-0.40 \mathrm{~m}$ from the useful area of each plot and between the rows of the previous crop to form a composite sample. The samples were dried, sieved (2-mm sieves) and analysed according to Cantarella et al. (1998) and Korndörfer et al. (1999) to determine chemical properties $\left(\mathrm{pH}, \mathrm{H}+\mathrm{Al}, \mathrm{Ca}, \mathrm{Mg}, \mathrm{K}, \mathrm{N}-\mathrm{NO}_{3}^{-}\right.$, $\mathrm{S}-\mathrm{SO}_{4}^{2-}$, base saturation, and $\mathrm{Si}$ ).

The soil $\mathrm{pH}$ was determined in a $0.01 \mathrm{~mol} \mathrm{~L}^{-1} \mathrm{CaCl}_{2}$ suspension (1:2.5 soil/solution). The total acidity $(\mathrm{H}, \mathrm{Al})$ was determined by extraction using calcium acetate $\left(0.5 \mathrm{~mol} \mathrm{~L}^{-1}\right.$ at $\left.\mathrm{pH} 7.0\right)$ and titration ( $0.025 \mathrm{~mol} \mathrm{~L}^{-1} \mathrm{NaOH}$ solution). The exchangeable $\mathrm{Ca}, \mathrm{Mg}$, and $\mathrm{K}$ were extracted using ion exchange resin (van Raij et al., 1986) and determined using atomic absorption spectrophotometry. Inorganic $\mathrm{N}$ was extracted using $1.0 \mathrm{~mol} \mathrm{~L}^{-1} \mathrm{KCl}$ and distilled using Devarda's alloy (Keeney and Nelson, 1982). Soil $\mathrm{SO}_{4}-\mathrm{S}$ analyses were performed through extraction using calcium phosphate $\left(0.01 \mathrm{~mol} \mathrm{~L}^{-1}\right)$ in a $1: 2.5$ soil/solution ratio, followed by the turbidimetric method using $\mathrm{BaSO}_{4}$ (Bardsley and Lancaster, 1960). The soluble Si concentration was determined using a $0.01 \mathrm{~mol} \mathrm{~L}^{-1} \mathrm{CaCl}_{2}$ solution (Korndörfer et al., 1999). Silicon determination was performed by beta-molybdosilicic complex formation (Kilmer, 1965) using a spectrophotometer at $660 \mathrm{~nm}$.

\subsection{Leaf sampling and chemical analysis methods}

When $50 \%$ of the panicles of the rice plants in each plot were at the flowering stage, 50 flag leaf samples were collected for nutrient concentration determination (Cantarella et al., 1997). The leaves were dried in a forced air oven at $65{ }^{\circ} \mathrm{C}$ for $72 \mathrm{~h}$, ground to pass through a 40-mesh stainless steel screen and analysed for nutrient concentration.

Analyses of P, K, Ca, Mg, and S concentrations were performed after nitric-perchloric acid digestion and were determined using atomic absorption spectrophotometry (Malavolta et al., 1997). Nitrogen was analysed using sulphuric acid digestion and the semi-micro Kjeldahl method (Malavolta et al., 1997).

The Si concentration in the flag leaves was assayed based on the procedure recommended by Elliott and Snyder (1991), adapted by Korndörfer et al. (1999). Plant tissue samples $(0.1 \mathrm{~g})$ were placed in polyethylene tubes and wetted using $2 \mathrm{~mL}$ of $50 \% \mathrm{H}_{2} \mathrm{O}_{2}$. Then, $3 \mathrm{~mL}$ of $50 \% \mathrm{NaOH}$ at room temperature was added to each tube. The tubes were placed in a double boiler for $1 \mathrm{~h}$ and then in an autoclave at $138 \mathrm{kPa}$ for $1 \mathrm{~h}$. After atmospheric pressure was reached, the tubes were removed, and $45 \mathrm{~mL}$ of water was added. After a 12-h period, a 1 - $\mathrm{mL}$ aliquot of the supernatant was set aside, and $15 \mathrm{~mL}$ of water, $1 \mathrm{~mL}$ of $\mathrm{HCl}\left(500 \mathrm{~g} \mathrm{~L}^{-1}\right)$, and $2 \mathrm{~mL}$ of ammonium molybdate were added. After 5 to $10 \mathrm{~min}, 2 \mathrm{~mL}$ of oxalic acid $\left(500 \mathrm{~g} \mathrm{~L}^{-1}\right)$ was added. The silicon concentration was determined at a wavelength of $410 \mathrm{~nm}$ using a spectrophotometer.

\subsection{Yield components and grain yield measurements}

When approximately $90 \%$ of the panicles had grains with a typical mature colouration, the following parameters were evaluated: the number of panicles $\mathrm{m}^{-2}$ (calculated by counting the number of panicles in an area of $2.0 \mathrm{~m}$ in the two central rows from the usable area of each plot), total number of spikelets panicle ${ }^{-1}$ (calculated by counting the number of spikelets in 20 panicles in the useable area), spikelet fertility [calculated using the following function: (number of grain-bearing spikelets/total number of spikelets per panicle $) \times 100$ ], and weight of 1000 grains (evaluated by randomly collecting and weighing four samples of 1000 grains from each plot (the values were adjusted to a moisture content of $\left.130 \mathrm{~g} \mathrm{~kg}^{-1}\right)$ ). A manual harvest was conducted, 

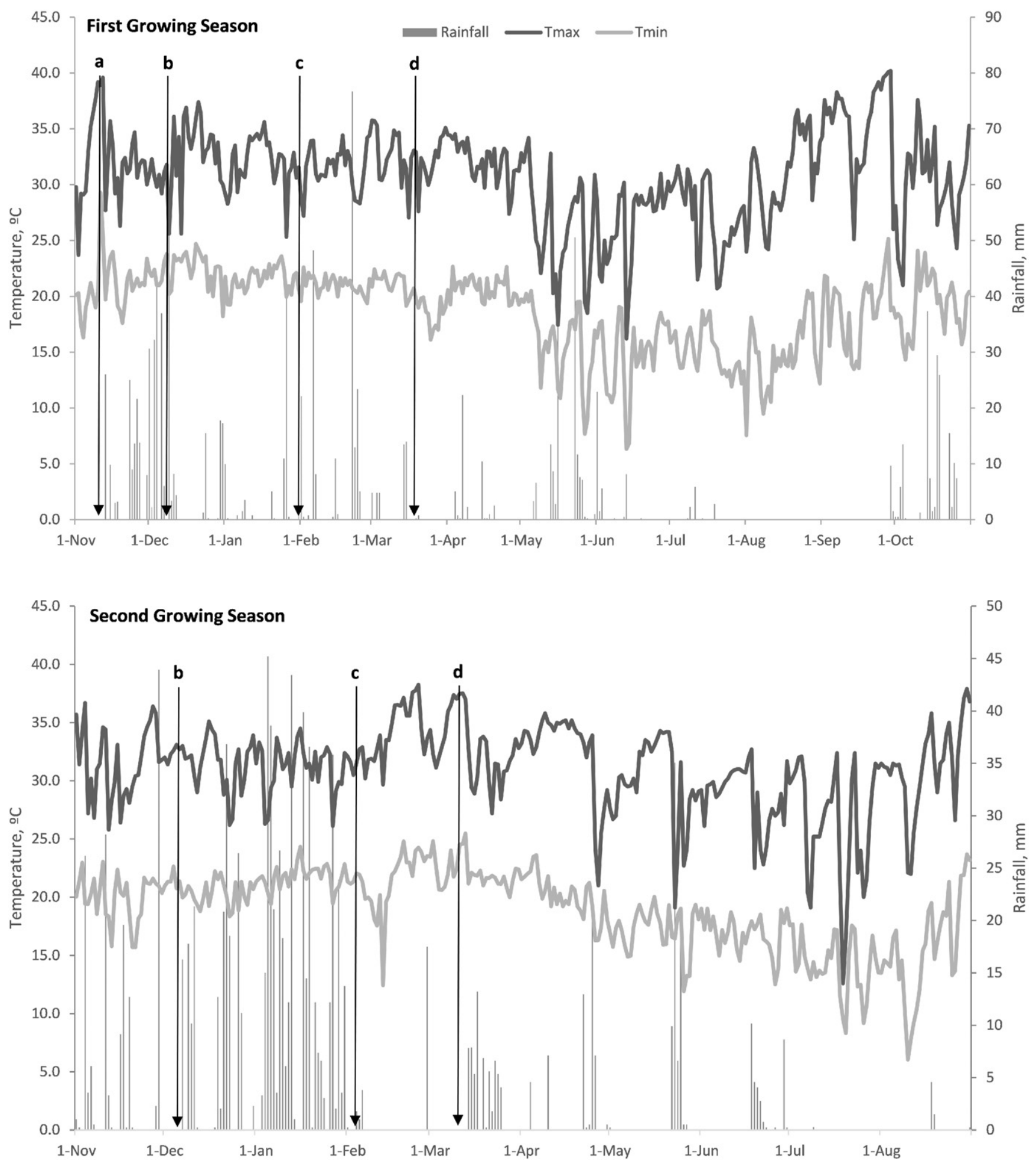

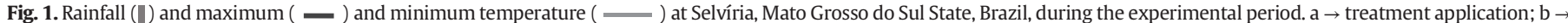
emergence; $c \rightarrow$ flowering; $d \rightarrow$ harvest.

and the panicles were dried in the sun for 1 to 2 days and later subjected to mechanical threshing using a research plot thresher. The grain yield (calculated from the weight of unhulled grain collected from the three central rows spanning five metres in each plot, eliminating $2.5 \mathrm{~m}$ on each side) and the values were adjusted to a moisture content of $130 \mathrm{~g} \mathrm{~kg}^{-1}$ and converted to $\mathrm{kg} \mathrm{ha}^{-1}$.

\subsection{Statistical analysis}

All data were analysed using two-way ANOVA in the statistical software package SAS®. The treatments and growing seasons (plant results only) were considered fixed effects. Significant differences between the means were determined using Fisher's protected LSD test. Effects were 
Table 2

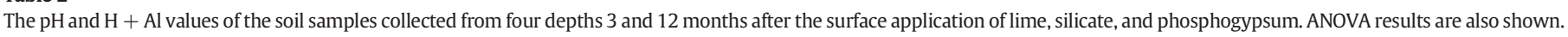

\begin{tabular}{|c|c|c|c|c|}
\hline \multirow{2}{*}{ Treatments } & \multicolumn{4}{|l|}{ Soil depth } \\
\hline & $0-0.05 \mathrm{~m}$ & $0.05-0.10 \mathrm{~m}$ & $0.10-0.20 \mathrm{~m}$ & $0.20-0.40 \mathrm{~m}$ \\
\hline & \multicolumn{4}{|l|}{$\mathrm{pH}\left(\mathrm{CaCl}_{2}\right)$} \\
\hline & \multicolumn{4}{|l|}{3 months } \\
\hline Control & $4.9 c^{\dagger}$ & $4.8 \mathrm{~b}$ & $4.8 \mathrm{a}$ & $4.6 \mathrm{a}$ \\
\hline Phosphogypsum & $5.2 \mathrm{~b}$ & $4.9 \mathrm{~b}$ & $4.9 \mathrm{a}$ & $4.7 \mathrm{a}$ \\
\hline Lime & $5.5 \mathrm{a}$ & $5.1 \mathrm{a}$ & $4.8 \mathrm{a}$ & $4.7 \mathrm{a}$ \\
\hline Silicate & $5.5 \mathrm{a}$ & $5.1 \mathrm{a}$ & $4.8 \mathrm{a}$ & $4.6 \mathrm{a}$ \\
\hline Lime + Silicate $(\operatorname{mix})$ & $5.6 a$ & $5.1 \mathrm{a}$ & $4.8 \mathrm{a}$ & $4.7 \mathrm{a}$ \\
\hline Lime + Phosphogypsum (mix) & $5.5 \mathrm{a}$ & $5.1 \mathrm{a}$ & $4.8 \mathrm{a}$ & $4.7 \mathrm{a}$ \\
\hline Silicate + Phosphogypsum (mix) & $5.6 a$ & $5.1 \mathrm{a}$ & $4.8 \mathrm{a}$ & $4.7 \mathrm{a}$ \\
\hline Lime + Silicate + Phosphogypsum (mix) & $5.6 a$ & $5.1 \mathrm{a}$ & $4.9 \mathrm{a}$ & $4.6 \mathrm{a}$ \\
\hline \multicolumn{5}{|l|}{ ANOVA (F probability) } \\
\hline Blocks & 0.266 & 0.279 & 0.414 & 0.387 \\
\hline Treatments & 0.030 & 0.046 & 0.294 & 0.416 \\
\hline \multirow[t]{2}{*}{ Orthogonal contrast $(W G \times G)$} & 0.444 & 0.605 & 0.707 & 0.653 \\
\hline & \multicolumn{4}{|l|}{12 months } \\
\hline Control & $4.8 \mathrm{c}$ & $4.6 \mathrm{c}$ & $4.8 \mathrm{~b}$ & $4.7 \mathrm{c}$ \\
\hline Phosphogypsum & $4.8 \mathrm{c}$ & $4.6 c$ & $4.8 \mathrm{~b}$ & $4.8 \mathrm{bc}$ \\
\hline Lime & $5.2 b$ & $4.8 \mathrm{~b}$ & $4.9 b$ & $4.8 \mathrm{bc}$ \\
\hline Silicate & $5.2 b$ & $4.8 \mathrm{~b}$ & $4.9 b$ & $4.9 \mathrm{~b}$ \\
\hline Lime + Silicate $(\operatorname{mix})$ & $5.2 \mathrm{~b}$ & $4.8 \mathrm{~b}$ & $4.9 b$ & $4.9 \mathrm{~b}$ \\
\hline Lime + Phosphogypsum (mix) & $5.4 a$ & $5.0 \mathrm{a}$ & $5.1 \mathrm{a}$ & $5.0 \mathrm{ab}$ \\
\hline Silicate + Phosphogypsum (mix) & $5.4 \mathrm{a}$ & $5.0 \mathrm{a}$ & $5.1 \mathrm{a}$ & $5.0 \mathrm{ab}$ \\
\hline Lime + Silicate + Phosphogypsum (mix) & $5.4 \mathrm{a}$ & $5.0 \mathrm{a}$ & $5.2 \mathrm{a}$ & $5.1 \mathrm{a}$ \\
\hline \multicolumn{5}{|l|}{ ANOVA ( $F$ probability) } \\
\hline Blocks & 0.099 & 0.081 & 0.153 & 0.836 \\
\hline Treatments & $<0.001$ & $<0.001$ & $<0.001$ & $<0.001$ \\
\hline \multirow[t]{3}{*}{ Orthogonal contrast $(W G \times G))^{\ddagger}$} & $<0.001$ & $<0.001$ & $<0.001$ & $<0.001$ \\
\hline & \multicolumn{4}{|l|}{$\mathrm{H}+\mathrm{Al}\left(\mathrm{mmol}_{\mathrm{c}} \mathrm{dm}^{-3}\right)$} \\
\hline & \multicolumn{4}{|l|}{3 months } \\
\hline Control & $39 a$ & $41 \mathrm{a}$ & $42 \mathrm{a}$ & $39 a$ \\
\hline Phosphogypsum & $38 a$ & $42 \mathrm{a}$ & $42 \mathrm{a}$ & $39 a$ \\
\hline Lime & $32 b$ & $40 a$ & $43 a$ & $37 a$ \\
\hline Silicate & $32 b$ & $40 a$ & $42 \mathrm{a}$ & $36 a$ \\
\hline Lime + Silicate (mix) & $28 b$ & $40 a$ & $42 a$ & $36 a$ \\
\hline Lime + Phosphogypsum (mix) & $32 b$ & $40 a$ & $43 a$ & $36 a$ \\
\hline Silicate + Phosphogypsum (mix) & $28 b$ & $38 \mathrm{a}$ & $43 a$ & $37 a$ \\
\hline Lime + Silicate + Phosphogypsum (mix) & $27 \mathrm{~b}$ & $39 a$ & $42 \mathrm{a}$ & $37 a$ \\
\hline \multicolumn{5}{|l|}{ ANOVA ( $F$ probability) } \\
\hline Blocks & 0.195 & 0.389 & 0.543 & 0.500 \\
\hline \multirow{3}{*}{ Orthogonal contrast $(W G \times G)^{\ddagger}$} & 0.042 & 0.219 & 0.583 & 0.602 \\
\hline & 0.421 & 0.612 & 0.635 & 0.696 \\
\hline & \multicolumn{4}{|l|}{12 months } \\
\hline Control & $42 \mathrm{a}$ & $46 a$ & $39 a$ & $36 a$ \\
\hline Phosphogypsum & $38 b$ & $45 a$ & $39 a$ & $36 a$ \\
\hline Lime & $33 c$ & $42 \mathrm{a}$ & $37 a$ & $33 a$ \\
\hline Silicate & $31 c$ & $42 \mathrm{a}$ & $38 a$ & $33 a$ \\
\hline Lime + Silicate $(\operatorname{mix})$ & $32 c$ & $42 \mathrm{a}$ & $38 a$ & $32 \mathrm{a}$ \\
\hline Lime + Phosphogypsum (mix) & $30 c$ & $40 a$ & $30 a$ & $30 a$ \\
\hline Silicate + Phosphogypsum (mix) & $30 c$ & $40 a$ & $31 \mathrm{a}$ & $30 a$ \\
\hline Lime + Silicate + Phosphogypsum (mix) & $30 c$ & $40 a$ & $30 a$ & $30 a$ \\
\hline \multicolumn{5}{|l|}{ ANOVA ( $F$ probability) } \\
\hline Blocks & 0.323 & 0.093 & 0.106 & 0.770 \\
\hline Treatments & $<0.001$ & 0.092 & 0.103 & 0.113 \\
\hline Orthogonal contrast $(\mathrm{WG} \times \mathrm{G})^{\ddagger}$ & 0.004 & 0.047 & $<0.001$ & 0.003 \\
\hline
\end{tabular}

${ }^{\dagger}$ Values followed by the same letter within a column are not significantly different at $\mathrm{p} \leq 0.05$ according to the LSD test.

$\ddagger$ Orthogonal contrast analysis between treatments with $(G)$ and without (WG) phosphogypsum ( $\mathrm{p} \leq 0.05$ ).

considered significant at $\mathrm{P} \leq 0.05$ for the soil chemical parameters, yield components and grain yield data. Orthogonal contrast analyses were performed to compare treatments with $(G)$ and without (WG) phosphogypsum (soil and plant results) and with (S) and without (WS) silicate (plant results only); these effects were considered significant at $\mathrm{P} \leq 0.05$.

\section{Results and discussion}

\subsection{Soil chemical characteristics}

The $\mathrm{pH}$ in the $0-0.05$ and $0.05-0.10-\mathrm{m}$ soil layers increased three months after amendment application (Table 1 ). This result is attributed to the low solubility and mobility of the carbonate- and silicate-based inputs. According to Pavan et al. (1984), the surface application of soil acidity amendments, such as Ca carbonate, increased the $\mathrm{pH}$ only in the surface soil layers; little or no change in $\mathrm{pH}$ occurred below a depth of $0.20 \mathrm{~m}$. In addition, these authors also found that phosphogypsum had little or no effect on soil $\mathrm{pH}$.

Although phosphogypsum is not considered an effective material for ameliorating soil acidity (Smith et al., 1994), we noticed that the individual addition of $3.0 \mathrm{Mg} \mathrm{ha}^{-1}$ of this by-product led to an increase of $0.3 \mathrm{pH}$ units in the $0-0.05-\mathrm{m}$ soil layer (Table 2). In areas of Peninsular Malaysia, Ismail et al. (1993) also reported increases in soil solution $\mathrm{pH}$ (from 4.2 to 4.5 ) resulting from the application of $4 \mathrm{Mg} \mathrm{ha}^{-1}$ of phosphogypsum. It is likely that these reactions result from anion 
Table 3.

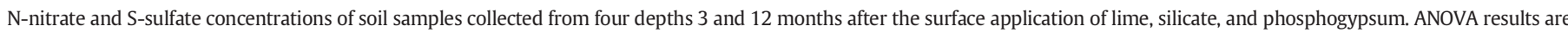
also shown.

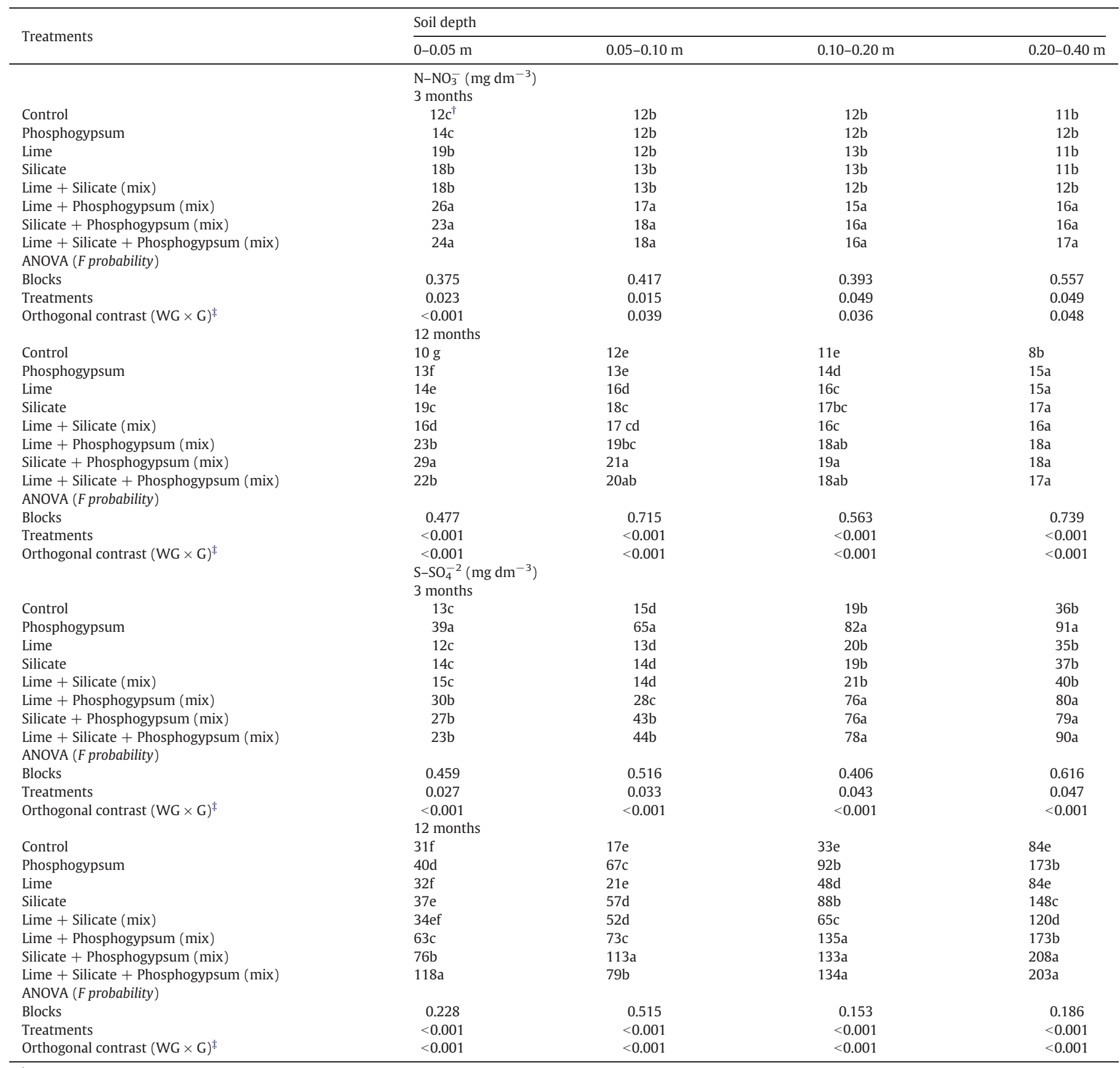

$\dagger$ Values followed by the same letter within a column are not significantly different at $p \leq 0.05$ according to the LSD test.

* Orthogonal contrast analysis between treatments with $(G)$ and without (WG) phosphogypsum ( $p \leq 0.05$ ).

exchange mechanisms, which involve the replacement of $\mathrm{OH}^{-}$by $\mathrm{SO}_{4}^{2-}$ in the colloidal soil complex, a process referred to as "self-liming" (Reeve and Sumner, 1972; Soratto and Crusciol, 2008a; Churka Blum et al., 2013).

In addition, phosphogypsum application may have reduced the chemical activity of $\mathrm{Al}^{3+}$, which reduces the $\mathrm{Al}$ hydrolysis process and consequently, the displacement of $\mathrm{H}^{+}$ions to solution, which is responsible for soil pH reduction (Shainberg et al., 1989; Alva and Gascho, 1991). This reaction can explain the positive effects of phosphogypsum when applied in mixtures with lime and/or silicate; these effects were observed 12 months after treatment establishment (Table 2), as confirmed by contrast orthogonal analysis. Results from tropical regions with high annual rainfall suggest that soil acidity amendments and phosphogypsum have positive effects on the amelioration of subsurface acidity in a relative short period of time. In a trial conducted in New South Wales, Australia, contradictory results was observed by Smith et al. (1994) in a region where the mean annual rainfall is approximately $800 \mathrm{~mm}$. These authors reported that surface liming combined with phosphogypsum did not increase soil pH below a depth of $0.05 \mathrm{~m} 18$ months after application. In addition to the intrinsic characteristics of this product, these results suggest that the action of acidity amendment materials in subsurface soil layers may vary depending on soil type, water availability (Oliveira and Pavan, 1996; Caires et al., 2005) and the presence of other substances, such as Ca sulphate.

Silicate is 6.78 times more soluble than Ca carbonate (Alcarde and Rodella, 2003), and silicate did not have a positive effect on soil pH 
Table 4

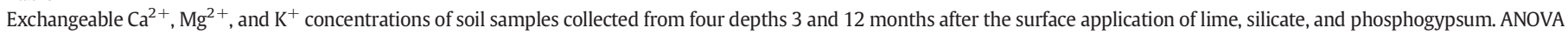
results are also shown.

\begin{tabular}{|c|c|c|c|c|}
\hline \multirow{2}{*}{ Treatments } & \multicolumn{4}{|l|}{ Soil depth } \\
\hline & $0-0.05 \mathrm{~m}$ & $0.05-0.10 \mathrm{~m}$ & $0.10-0.20 \mathrm{~m}$ & $0.20-0.40 \mathrm{~m}$ \\
\hline & \multicolumn{4}{|c|}{ Exchangeable $\mathrm{Ca}^{2+}\left(\mathrm{mmol}_{\mathrm{c}} \mathrm{dm}^{-3}\right)$} \\
\hline Control & $20 \mathrm{~d}^{\dagger}$ & $19 c$ & $18 \mathrm{a}$ & $11 \mathrm{a}$ \\
\hline Phosphogypsum & $31 c$ & $25 b$ & $20 a$ & $12 \mathrm{a}$ \\
\hline Lime & $40 \mathrm{~b}$ & $24 b$ & $18 \mathrm{a}$ & $11 \mathrm{a}$ \\
\hline Silicate & $42 b$ & $25 b$ & $19 a$ & $12 \mathrm{a}$ \\
\hline Lime + Silicate $(\operatorname{mix})$ & $42 b$ & $30 a$ & $19 a$ & $12 \mathrm{a}$ \\
\hline Lime + Phosphogypsum (mix) & $50 a$ & $31 a$ & $19 a$ & $13 a$ \\
\hline Silicate + Phosphogypsum (mix) & $51 a$ & $30 a$ & $20 a$ & $13 a$ \\
\hline Lime + Silicate + Phosphogypsum (mix) & $52 a$ & $31 a$ & $21 \mathrm{a}$ & $13 a$ \\
\hline \multicolumn{5}{|l|}{ ANOVA ( $F$ probability) } \\
\hline Blocks & 0.141 & 0.200 & 0.355 & 0.297 \\
\hline Treatments & $<0.001$ & 0.039 & 0.125 & 0.227 \\
\hline \multirow[t]{2}{*}{ Orthogonal contrast $(W G \times G)^{\ddagger}$} & $<0.001$ & 0.023 & 0.157 & 0.172 \\
\hline & \multicolumn{4}{|l|}{12 months } \\
\hline Control & $18 \mathrm{f}$ & $16 c$ & $15 f$ & $12 c$ \\
\hline Phosphogypsum & $18 \mathrm{f}$ & $18 \mathrm{c}$ & $17 \mathrm{e}$ & $15 b$ \\
\hline Lime & $24 d$ & $21 b$ & $20 d$ & $16 b$ \\
\hline Silicate & $22 \mathrm{e}$ & $19 b c$ & $22 c$ & $17 \mathrm{~b}$ \\
\hline Lime + Silicate (mix) & $25 c$ & $20 b c$ & $21 \mathrm{~cd}$ & $16 b$ \\
\hline Lime + Phosphogypsum (mix) & $37 b$ & $27 a$ & $24 b$ & 18ab \\
\hline Silicate + Phosphogypsum (mix) & $43 a$ & $28 a$ & $28 a$ & $20 a$ \\
\hline Lime + Silicate + Phosphogypsum (mix) & $44 a$ & $27 a$ & $25 b$ & 19ab \\
\hline \multicolumn{5}{|l|}{ ANOVA (F probability) } \\
\hline Blocks & 0.137 & 0.110 & 0.083 & 0.392 \\
\hline Treatments & $<0.001$ & $<0.001$ & $<0.001$ & $<0.001$ \\
\hline \multirow[t]{3}{*}{ Orthogonal contrast $(W G \times G)^{\ddagger}$} & $<0.001$ & $<0.001$ & $<0.001$ & $<0.001$ \\
\hline & \multicolumn{4}{|c|}{ Exchangeable $\mathrm{Mg}^{2+}\left(\mathrm{mmol}_{\mathrm{c}} \mathrm{dm}^{-3}\right)$} \\
\hline & 3 months & & & \\
\hline Control & $12 \mathrm{c}$ & $9 c$ & $12 \mathrm{a}$ & $8 \mathrm{a}$ \\
\hline Phosphogypsum & $10 c$ & $10 \mathrm{c}$ & $12 \mathrm{a}$ & $9 \mathrm{a}$ \\
\hline Lime & $28 a$ & $17 a$ & $10 a$ & $9 \mathrm{a}$ \\
\hline Silicate & $28 a$ & $17 a$ & $10 a$ & $9 \mathrm{a}$ \\
\hline Lime + Silicate $(\operatorname{mix})$ & $29 a$ & $17 a$ & $10 \mathrm{a}$ & $8 \mathrm{a}$ \\
\hline Lime + Phosphogypsum (mix) & $23 b$ & $14 \mathrm{~b}$ & $11 \mathrm{a}$ & $9 \mathrm{a}$ \\
\hline Silicate + Phosphogypsum (mix) & $22 b$ & $14 \mathrm{~b}$ & $11 \mathrm{a}$ & $8 \mathrm{a}$ \\
\hline Lime + Silicate + Phosphogypsum (mix) & $23 b$ & $15 b$ & $12 \mathrm{a}$ & $8 \mathrm{a}$ \\
\hline ANOVA (F probability) & & & & \\
\hline Blocks & 0.144 & 0.100 & 0.257 & 0.227 \\
\hline Treatments & 0.032 & 0.040 & 0.430 & 0.501 \\
\hline Orthogonal contrast $(W G \times G)$ & $<0.001$ & $<0.001$ & 0.633 & 0.508 \\
\hline & 12 months & & & \\
\hline Control & $10.7 d$ & $7.3 e$ & $9.4 a$ & $9.0 \mathrm{a}$ \\
\hline Phosphogypsum & $10.3 d$ & $5.9 f$ & $10.6 a$ & $10.0 \mathrm{a}$ \\
\hline Lime & $19.7 \mathrm{a}$ & $11.5 \mathrm{a}$ & $10.4 \mathrm{a}$ & $9.1 \mathrm{a}$ \\
\hline Silicate & $17.0 \mathrm{~b}$ & $10.3 b c$ & $9.8 \mathrm{a}$ & $9.8 \mathrm{a}$ \\
\hline Lime + Silicate (mix) & $19.0 \mathrm{a}$ & $11.2 \mathrm{ab}$ & $10.0 \mathrm{a}$ & $9.4 a$ \\
\hline Lime + Phosphogypsum (mix) & $12.1 \mathrm{c}$ & $9.2 \mathrm{~d}$ & $11.5 \mathrm{a}$ & $11.0 \mathrm{a}$ \\
\hline Silicate + Phosphogypsum (mix) & $12.4 \mathrm{c}$ & $7.8 \mathrm{e}$ & $10.7 \mathrm{a}$ & $12.1 \mathrm{a}$ \\
\hline Lime + Silicate + Phosphogypsum (mix) & $11.6 \mathrm{~cd}$ & $9.4 \mathrm{~cd}$ & $11.0 \mathrm{a}$ & $11.0 \mathrm{a}$ \\
\hline ANOVA ( $F$ probability) & & & & \\
\hline Blocks & 0.115 & 0.051 & 0.473 & 0.315 \\
\hline Treatments & $<0.001$ & $<0.001$ & 0.423 & 0.077 \\
\hline Orthogonal contrast $(W G \times G) \ddagger$ & $<0.001$ & $<0.001$ & 0.036 & $<0.001$ \\
\hline & Exchangeab & $-3)$ & & \\
\hline & 3 months & & & \\
\hline Control & $3.2 \mathrm{a}$ & $1.4 \mathrm{a}$ & $1.2 \mathrm{a}$ & $0.8 \mathrm{a}$ \\
\hline Phosphogypsum & $3.0 \mathrm{a}$ & $1.4 \mathrm{a}$ & $1.1 \mathrm{a}$ & $0.8 \mathrm{a}$ \\
\hline Lime & $3.2 \mathrm{a}$ & $1.6 a$ & $1.2 \mathrm{a}$ & $1.0 \mathrm{a}$ \\
\hline Silicate & $3.0 \mathrm{a}$ & $1.5 a$ & $1.2 \mathrm{a}$ & $0.9 a$ \\
\hline Lime + Silicate $(\operatorname{mix})$ & 2.9a & $1.6 a$ & $1.1 \mathrm{a}$ & $0.8 \mathrm{a}$ \\
\hline Lime + Phosphogypsum (mix) & $2.9 \mathrm{a}$ & $1.5 \mathrm{a}$ & $1.2 \mathrm{a}$ & $1.0 \mathrm{a}$ \\
\hline Silicate + Phosphogypsum (mix) & $3.0 \mathrm{a}$ & $1.4 \mathrm{a}$ & $1.1 \mathrm{a}$ & $0.9 a$ \\
\hline Lime + Silicate + Phosphogypsum (mix) & $3.0 \mathrm{a}$ & $1.4 \mathrm{a}$ & $1.2 \mathrm{a}$ & $0.9 a$ \\
\hline ANOVA ( $F$ probability) & & & & \\
\hline Blocks & 0.222 & 0.177 & 0.200 & 0.585 \\
\hline Treatments & 0.203 & 0.193 & 0.196 & 0.275 \\
\hline Orthogonal contrast $(W G \times G)$ & 0.429 & 0.376 & 0.312 & 0.479 \\
\hline & 12 months & & & \\
\hline Control & $3.9 a$ & $2.5 a$ & $2.4 \mathrm{a}$ & $2.5 \mathrm{a}$ \\
\hline Phosphogypsum & $1.9 \mathrm{~d}$ & $1.1 \mathrm{f}$ & $1.5 b$ & $1.3 \mathrm{~b}$ \\
\hline Lime & $2.5 b$ & $2.3 \mathrm{~b}$ & $1.1 \mathrm{e}$ & $0.8 \mathrm{~d}$ \\
\hline
\end{tabular}


Table 4 (continued)

\begin{tabular}{|c|c|c|c|c|}
\hline \multirow{2}{*}{ Treatments } & \multicolumn{4}{|l|}{ Soil depth } \\
\hline & $0-0.05 \mathrm{~m}$ & $0.05-0.10 \mathrm{~m}$ & $0.10-0.20 \mathrm{~m}$ & $0.20-0.40 \mathrm{~m}$ \\
\hline Silicate & $2.6 \mathrm{~b}$ & $2.0 \mathrm{c}$ & $1.3 \mathrm{c}$ & $0.9 \mathrm{~d}$ \\
\hline Lime + Silicate (mix) & $2.6 b$ & $2.1 \mathrm{c}$ & $1.2 \mathrm{~d}$ & $0.8 \mathrm{~d}$ \\
\hline Lime + Phosphogypsum (mix) & $1.9 \mathrm{~d}$ & $1.5 \mathrm{~d}$ & $1.5 \mathrm{~b}$ & $1.1 \mathrm{c}$ \\
\hline Silicate + Phosphogypsum (mix) & $2.2 \mathrm{c}$ & $1.2 \mathrm{e}$ & $1.5 \mathrm{~b}$ & $1.3 \mathrm{~b}$ \\
\hline Lime + Silicate + Phosphogypsum (mix) & $2.1 \mathrm{c}$ & $1.3 e$ & $1.5 \mathrm{~b}$ & $1.1 \mathrm{c}$ \\
\hline \multicolumn{5}{|l|}{ ANOVA (F probability) } \\
\hline Blocks & 0.246 & 0.011 & 0.099 & 0.653 \\
\hline Treatments & $<0.001$ & $<0.001$ & $<0.001$ & $<0.001$ \\
\hline Orthogonal contrast $(W G \times G)^{ \pm}$ & $<0.001$ & $<0.001$ & $<0.001$ & 0.316 \\
\hline
\end{tabular}

$\dagger$ Values followed by the same letter within a column are not significantly different at $\mathrm{p} \leq 0.05$ according to the LSD test.

* Orthogonal contrast analysis between treatments with $(G)$ and without $(W G)$ phosphogypsum $(p \leq 0.05)$.

compared with lime (Table 2). Despite its ineffectiveness, silicate is considered a good alternative to replace lime, mainly in regions with extensive agriculture where the cost of lime is high (Smith et al., 1994). In a trial conducted in an Oxisol without supplementary irrigation, Castro and Crusciol (2013) reported that lime and silicate increased the $\mathrm{pH}$ in the topsoil layer. However, 12 months after treatment establishment, liming only influenced the $\mathrm{pH}$ above a depth of $0.10 \mathrm{~m}$, while $\mathrm{Ca}$ and $\mathrm{Mg}$ silicate increased $\mathrm{pH}$ to a depth of up to $0.2 \mathrm{~m}$.

In the present study, changes in potential acidity $(\mathrm{H}+\mathrm{Al})$ occurred exclusively in the $0-0.05-\mathrm{m}$ layer from the third month after the surface application of the treatments (Table 2). The neutralization of acidity and the increase in $\mathrm{pH}$ can be explained by an increase in the amount of hydroxyls $\left(\mathrm{OH}^{-}\right)$, which resulted from the application of the amendments, such as lime and silicate (McLean, 1982). The phosphogypsum application decreased $\mathrm{H}+\mathrm{Al}$ only after 12 months following treatment establishment. Despite the reactions described previously, the fluoride in phosphogypsum can bond with free $\mathrm{Al}^{3+}$, forming an $\mathrm{Al}-\mathrm{F}$ complex that can reduce exchangeable $\mathrm{Al}$ and, consequently, $\mathrm{H}+\mathrm{Al}$ (Alva et al., 1988). The effect of the combination with respect to reducing the acidity potential was small and was not detected by Fisher's LSD test; however, orthogonal contrast analysis confirmed that phosphogypsum decreased $\mathrm{H}+\mathrm{Al}$. This reaction involves the displacement of free $\mathrm{Al}^{3+}$ by the $\mathrm{Ca}^{2+}$ from the exchange complex and consequently the formation of the $\mathrm{AlSO}_{4}^{+}$ion pair, a species form that decreases free $\mathrm{Al}^{3+}$ in soil solution (Sumner, 1993; Peregrina et al., 2006, 2008). Similar effects were reported by Caires et al. (2006) 11 months after surface liming. In a subtropical Oxisol previously used as pastureland, these authors observed small effects of $\mathrm{Ca}$ carbonate on $\mathrm{H}+\mathrm{Al}$ reduction in the uppermost soil layer, and no effects below a depth of $0.05 \mathrm{~m}$.

The surface application of acidity amendments increased available $\mathrm{N}-\mathrm{NO}_{3}^{-}$in the $0-0.05 \mathrm{~m}$ soil layer (Table 3); however, higher levels were observed when phosphogypsum was added as a mixture. Sierra et al. (2001) suggested that the nitrification process can be affected by factors that influence soil electrochemical properties, mainly those that influence soil pH (Chung and Zasoski, 1993). In a trial conducted in an acid soil (initial $\mathrm{pH} 4.8$ ) with an organic matter content of 3.5\% and a clay content of $22 \%$, Dancer et al. (1973) confirmed a positive correlation between soil $\mathrm{pH}$ and $\mathrm{NO}_{3}^{-}$levels $(\mathrm{r}=0.92)$. These authors reported that a pH change from 4.8 to 6.5 resulted in a fivefold increase in the soil $\mathrm{NO}_{3}^{-}$content. In this context, we suggest that lime and silicate application may have a strong influence on soil $\mathrm{NO}_{3}^{-}$.

For both soil sampling periods, the ability of phosphogypsum to increase the $\mathrm{N}-\mathrm{NO}_{3}^{-}$concentration compared with the application of individual soil acidity amendments is supposedly related to the anion-exchange phenomenon. Kinjo and Pratt (1971) studied the competitive effects of $\mathrm{SO}_{4}^{2-}$ and $\mathrm{NO}_{3}^{-}$adsorption and concluded that the amount of $\mathrm{NO}_{3}^{-}$in the soil solution increased linearly with the addition of $\mathrm{SO}_{4}^{2-}$ sources because of higher energy retention in the positively charged colloidal complexes. This competitive adsorption effect can explain the positive effect of phosphogypsum on available $\mathrm{N}-\mathrm{NO}_{3}^{-}$.
Phosphogypsum is a good alternative that can increase the amount of $\mathrm{N}$ in the soil profile. Furthermore, Crusciol et al. (2011) reported that higher $\mathrm{N}-\mathrm{NO}_{3}^{-}$levels in soil may reduce the negative effects caused by free $\mathrm{Al}^{3+}$

Regardless of the soil sampling time and type of mixture, the phosphogypsum-based treatments resulted in higher $\mathrm{S}_{-} \mathrm{SO}_{4}^{2-}$ concentrations in all soil layers (Table 3 ), which confirms the results obtained in several studies (Reeve and Sumner, 1972; Farina et al., 2000; Caires et al., 2011). It is important to emphasize that three months after treatment establishment, the individual application of phosphogypsum resulted in higher $\mathrm{S}_{-} \mathrm{SO}_{4}^{2-}$ concentrations in the topsoil layers $(0-0.10 \mathrm{~m})$. In addition to the effect of the acidity amendments, i.e., increasing the negative charges in soils with variable charges (Ji, 1997), the application of lime and/or silicate combined with Ca sulphate increased the amount of $\mathrm{Ca}$ and $\mathrm{Mg}$ in the soil solution, which resulted in a greater downward movement of $\mathrm{SO}_{4}^{2-}$ and consequently, neutral species formation $\left(\mathrm{CaSO}_{4}^{0}\right.$ and $\left.\mathrm{MgSO}_{4}^{0}\right)$. This phenomenon can result in the removal of considerable quantities of $\mathrm{Ca}, \mathrm{Mg}$ and $\mathrm{K}$ from the soil surface layers (O'Brien and Sumner, 1988; Churka Blum et al., 2013), making them more available at depths below $0.20 \mathrm{~m}$, as was observed in this study. The phosphogypsum and silicate mixture provided more $\mathrm{S}_{-} \mathrm{SO}_{4}^{2-}$ in the soil surface layers $(0-0.05$ and $0.05-0.10 \mathrm{~m}) 12$ months after treatment establishment (Table 3 ). It is likely that this effect is related to sulphate release, which was increased by silicate adsorption (Rãjan and Fox, 1975). Interactive effects between inorganic anions and soil colloids were reported by Haynes (1982). Castro and Crusciol et al. (2013) observed higher $\mathrm{PO}_{4}^{2-}$ availability in a Brazilian Oxisol after the surface application of $\mathrm{Ca}$ and $\mathrm{Mg}$ silicate.

Regardless of the type of material used, the levels of exchangeable $\mathrm{Ca}$ increased in the soil surface layers $(0-0.05$ and $0.05-0.10 \mathrm{~m})$ in the third month after treatment establishment (Table 4). However, at the 12th month, the concentrations of $\mathrm{Ca}$ increased in all layers, but higher concentrations were observed when phosphogypsum was associated with the acidity amendments. The mixture reaction proved satisfactory in improving the chemical properties of the soil subsurface layers. Similar positive effects of phosphogypsum were observed by Caires et al. (2011) nine months after surface application (in this case, Ca sulphate was not mixed with the soil acidity amendments). According to Caires et al. (2008a), the ability of phosphogypsum to increase the Ca levels in the lowest acidic soil layers can result in greater proliferation of roots at greater depths, increasing the efficiency of nutrient and water absorption by plants.

For both soil sampling periods, the surface application of lime and/or silicate resulted in a larger amount of exchangeable $\mathrm{Mg}$ present in the shallowest layers (0-0.05 and $0.05-0.10 \mathrm{~m}$ ) (Table 4). The use of phosphogypsum combined with the soil acidity amendments reduced the available $\mathrm{Mg}$ in the uppermost soil layers. Other studies have confirmed that phosphogypsum application increased the downward movement of exchangeable $\mathrm{Mg}$ to the deeper layers (Oliveira and Pavan, 1996; Soratto and Crusciol, 2008a), but in this scenario, i.e., a tropical region under irrigation, the movement of $\mathrm{Mg}$ through the soil 
Table 5

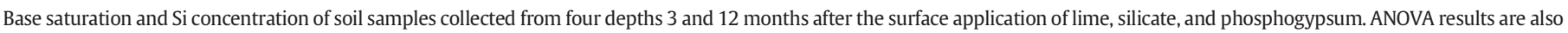
shown.

\begin{tabular}{|c|c|c|c|c|}
\hline \multirow{2}{*}{ Treatments } & \multicolumn{4}{|l|}{ Soil depth } \\
\hline & $0-0.05 \mathrm{~m}$ & $0.05-0.10 \mathrm{~m}$ & $0.10-0.20 \mathrm{~m}$ & $0.20-0.40 \mathrm{~m}$ \\
\hline & \multicolumn{4}{|l|}{ Base saturation (\%) } \\
\hline & \multicolumn{4}{|l|}{3 months } \\
\hline Control & $47 c^{\dagger}$ & $42 b$ & $43 a$ & $34 a$ \\
\hline Phosphogypsum & $56 \mathrm{~b}$ & $46 b$ & $44 a$ & $36 a$ \\
\hline Lime & $69 a$ & $52 a$ & $40 a$ & $36 a$ \\
\hline Silicate & $70 a$ & $53 a$ & $42 \mathrm{a}$ & $38 a$ \\
\hline Lime + Silicate $(\operatorname{mix})$ & $73 a$ & $55 a$ & $42 a$ & $37 a$ \\
\hline Lime + Phosphogypsum (mix) & $70 a$ & $54 a$ & $42 \mathrm{a}$ & $39 a$ \\
\hline Silicate + Phosphogypsum (mix) & $73 a$ & $54 a$ & $43 \mathrm{a}$ & $37 a$ \\
\hline Lime + Silicate + Phosphogypsum (mix) & $74 a$ & $55 a$ & $45 \mathrm{a}$ & $37 a$ \\
\hline \multicolumn{5}{|l|}{ ANOVA ( $F$ probability) } \\
\hline Blocks & 0.101 & 0.135 & 0.197 & 0.563 \\
\hline Treatments & 0.027 & 0.031 & 0.251 & 0.305 \\
\hline \multirow[t]{2}{*}{ Orthogonal contrast $(W G \times G)^{\ddagger}$} & 0.166 & 0.209 & 0.256 & 0.363 \\
\hline & \multicolumn{4}{|l|}{12 months } \\
\hline Control & $44 d$ & $35 c$ & $41 c$ & $40 c$ \\
\hline Phosphogypsum & $44 d$ & $36 c$ & $44 \mathrm{~b}$ & $42 \mathrm{bc}$ \\
\hline Lime & $58 \mathrm{c}$ & $45 b$ & $46 \mathrm{~b}$ & $44 \mathrm{~b}$ \\
\hline Silicate & $57 c$ & $43 b$ & $46 b$ & $45 b$ \\
\hline Lime + Silicate (mix) & $59 c$ & $44 \mathrm{~b}$ & $46 \mathrm{~b}$ & $45 b$ \\
\hline Lime + Phosphogypsum (mix) & $63 b$ & $49 a$ & $55 a$ & $50 a$ \\
\hline Silicate + Phosphogypsum (mix) & $67 a$ & $49 a$ & $57 a$ & $53 a$ \\
\hline Lime + Silicate + Phosphogypsum (mix) & $66 a$ & $49 a$ & $56 a$ & $51 \mathrm{a}$ \\
\hline \multicolumn{5}{|l|}{ ANOVA (F probability) } \\
\hline Blocks & 0.087 & 0.020 & 0.151 & 0.841 \\
\hline Treatments & $<0.001$ & $<0.001$ & $<0.001$ & $<0.001$ \\
\hline \multirow[t]{3}{*}{ Orthogonal contrast $(W G \times G)^{\ddagger}$} & $<0.001$ & $<0.001$ & $<0.001$ & $<0.001$ \\
\hline & \multirow{2}{*}{\multicolumn{4}{|c|}{$\mathrm{Si}\left(\mathrm{mg} \mathrm{dm}^{-3}\right)$}} \\
\hline & & & & \\
\hline Control & $4.1 \mathrm{~d}$ & $4.0 \mathrm{e}$ & $4.0 \mathrm{a}$ & $4.1 \mathrm{a}$ \\
\hline Phosphogypsum & $5.1 \mathrm{c}$ & $4.8 \mathrm{~d}$ & $4.1 \mathrm{a}$ & $4.0 \mathrm{a}$ \\
\hline Lime & $5.9 \mathrm{~b}$ & $5.7 \mathrm{c}$ & $4.2 \mathrm{a}$ & $4.0 \mathrm{a}$ \\
\hline Silicate & 7.3a & $8.0 \mathrm{a}$ & $4.4 a$ & $4.1 \mathrm{a}$ \\
\hline Lime + Silicate $(\operatorname{mix})$ & $6.8 \mathrm{a}$ & $7.1 \mathrm{~b}$ & $4.3 a$ & $4.2 \mathrm{a}$ \\
\hline Lime + Phosphogypsum (mix) & $6.0 \mathrm{~b}$ & $6.1 \mathrm{c}$ & $4.1 \mathrm{a}$ & $4.0 \mathrm{a}$ \\
\hline Silicate + Phosphogypsum (mix) & $7.0 \mathrm{a}$ & 7.9a & $4.3 a$ & $4.2 \mathrm{a}$ \\
\hline Lime + Silicate + Phosphogypsum (mix) & $7.3 a$ & $7.0 \mathrm{~b}$ & $4.4 a$ & $4.1 \mathrm{a}$ \\
\hline \multicolumn{5}{|l|}{ ANOVA (F probability) } \\
\hline Blocks & 0.123 & 0.175 & 0.444 & 0.511 \\
\hline Treatments & 0.016 & 0.039 & 0.284 & 0.312 \\
\hline \multirow{2}{*}{ Orthogonal contrast $(W G \times G)^{\ddagger}$} & 0.136 & 0.164 & 0.419 & 0.469 \\
\hline & \multicolumn{4}{|l|}{12 months } \\
\hline Control & $5.5 \mathrm{~d}$ & $5.7 \mathrm{~d}$ & $5.1 \mathrm{e}$ & $4.5 \mathrm{e}$ \\
\hline Phosphogypsum & $6.1 \mathrm{~d}$ & $5.7 \mathrm{~d}$ & $6.0 \mathrm{~d}$ & $4.6 \mathrm{e}$ \\
\hline Lime & $6.9 \mathrm{c}$ & $5.7 \mathrm{~d}$ & $6.3 \mathrm{~cd}$ & $5.5 \mathrm{~d}$ \\
\hline Silicate & $12.5 \mathrm{a}$ & $11.9 \mathrm{a}$ & $11.9 \mathrm{a}$ & $9.0 \mathrm{a}$ \\
\hline Lime + Silicate (mix) & $8.1 \mathrm{~b}$ & $7.0 \mathrm{bc}$ & $6.8 \mathrm{bc}$ & $6.2 \mathrm{c}$ \\
\hline Lime + Phosphogypsum (mix) & $6.8 \mathrm{c}$ & $6.6 \mathrm{c}$ & $6.2 \mathrm{~cd}$ & $5.4 \mathrm{~d}$ \\
\hline Silicate + Phosphogypsum (mix) & $8.6 \mathrm{~b}$ & $7.5 b$ & $7.4 \mathrm{~b}$ & $7.0 \mathrm{~b}$ \\
\hline Lime + Silicate + Phosphogypsum (mix) & $7.2 \mathrm{c}$ & $6.7 \mathrm{c}$ & $6.5 \mathrm{~cd}$ & $6.0 \mathrm{c}$ \\
\hline \multicolumn{5}{|l|}{ ANOVA (F probability) } \\
\hline Blocks & 0.472 & 0.123 & 0.291 & 0.110 \\
\hline Treatments & $<0.001$ & $<0.001$ & $<0.001$ & $<0.001$ \\
\hline Orthogonal contrast $(W G \times G)$ & 0.123 & 0.093 & 0.158 & 0.242 \\
\hline
\end{tabular}

$\dagger$ Values followed by the same letter within a column are not significantly different at $\mathrm{p} \leq 0.05$ according to the LSD test.

$\ddagger$ Orthogonal contrast analysis between treatments with $(G)$ and without $(W G)$ phosphogypsum $(p \leq 0.05)$.

profile was minimal, which resulted in a small increase in exchangeable $\mathrm{Mg}$ in the lower layers (0.10-0.20 $\mathrm{m}$ and $0.20-0.40 \mathrm{~m})$, as confirmed by orthogonal contrast analysis. It is important to emphasize that even with the use of phosphogypsum combined with the soil acidity amendments, the treatments provided sufficient levels of exchangeable $\mathrm{Mg}$ above a depth of $0.20 \mathrm{~m}\left(>8 \mathrm{mmol}_{\mathrm{c}} \mathrm{dm}^{-3}\right.$ ) (Caires et al., 2011).

Three months after treatment establishment, the soil exchangeable $\mathrm{K}$ content was not influenced by the surface application of lime, silicate, or phosphogypsum, which shows that $\mathrm{K}$ leaching did not occur in a short period of time (Table 4). However, Oates and Caldwell (1985) reported that this effect can vary with the amount of phosphogypsum. Furthermore, the fertilizer added one month after the application of the $\mathrm{Ca}, \mathrm{Mg}$, and sulphate sources, which may have masked the influence of these materials on the soil K content. Some studies have emphasized the K leaching effect caused by phosphogypsum application (Alva and Gascho, 1991; O'Brien and Sumner, 1988); however, Caires et al. (2011) showed that $\mathrm{K}$ losses can be low and vary according to the soil type. A lower $\mathrm{K}$ availability in the surface layers (0-0.05 and $0.05-$ $0.10 \mathrm{~m}$ ) was only observed 12 months after treatment application. This can be explained by the action of $\mathrm{SO}_{4}^{2-}$ and $\mathrm{NO}_{3}^{-}$through the formation of ionic complexes, which occurs with $\mathrm{Ca}$ and $\mathrm{Mg}$, and the water infiltration rate during the period between soil sampling (Farina et al., 2000; Qafoku and Sumner, 2001).

An increase in the base saturation values above a $0.10-\mathrm{m}$ depth was observed three months after treatment establishment, which is related to increasing $\mathrm{Ca}$ and $\mathrm{Mg}$ levels in the soil surface layers, as discussed 
Table 6

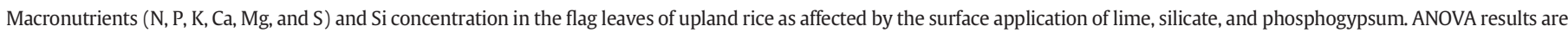
also shown.

\begin{tabular}{|c|c|c|c|c|c|c|c|}
\hline & $\mathrm{N}$ & $\mathrm{P}$ & $\mathrm{K}$ & $\mathrm{Ca}$ & $\mathrm{Mg}$ & $\mathrm{S}$ & $\mathrm{Si}$ \\
\hline & \multicolumn{7}{|l|}{$\left(\mathrm{g} \mathrm{kg}^{-1}\right)$} \\
\hline \multicolumn{8}{|l|}{ Treatments } \\
\hline Control & $31 a^{\dagger}$ & $1.8 \mathrm{a}$ & $17 a$ & $4.6 a$ & $1.8 \mathrm{a}$ & $2.8 \mathrm{~b}$ & $19 c$ \\
\hline Phosphogypsum & $32 \mathrm{a}$ & 1.9a & $17 a$ & $4.6 a$ & $1.8 \mathrm{a}$ & $3.5 a$ & $19 c$ \\
\hline Lime & $32 a$ & $1.9 \mathrm{a}$ & $17 \mathrm{a}$ & $4.7 \mathrm{a}$ & $1.8 \mathrm{a}$ & $2.9 \mathrm{~b}$ & $20 \mathrm{bc}$ \\
\hline Silicate & $33 a$ & $1.9 \mathrm{a}$ & $16 a$ & $4.9 \mathrm{a}$ & $1.9 \mathrm{a}$ & $2.7 \mathrm{~b}$ & $29 a$ \\
\hline Lime + Silicate $(\operatorname{mix})$ & $33 a$ & $1.9 \mathrm{a}$ & $16 a$ & $4.8 \mathrm{a}$ & $1.9 \mathrm{a}$ & $2.7 \mathrm{~b}$ & $24 \mathrm{~b}$ \\
\hline Lime + Phosphogypsum (mix) & $33 a$ & $1.9 \mathrm{a}$ & $16 a$ & $4.9 \mathrm{a}$ & $1.8 \mathrm{a}$ & $3.4 \mathrm{a}$ & $21 \mathrm{bc}$ \\
\hline Silicate + Phosphogypsum (mix) & $34 a$ & $1.9 \mathrm{a}$ & $15 a$ & $4.9 \mathrm{a}$ & $1.9 \mathrm{a}$ & $3.5 a$ & $22 \mathrm{bc}$ \\
\hline Lime + Silicate + Phosphogypsum (mix) & $33 a$ & $1.9 \mathrm{a}$ & $16 a$ & $5.0 \mathrm{a}$ & $1.8 \mathrm{a}$ & $3.5 a$ & $22 \mathrm{bc}$ \\
\hline \multicolumn{8}{|l|}{ Growing season } \\
\hline First & $35 a$ & $1.7 \mathrm{~b}$ & $15 b$ & $4.4 \mathrm{~b}$ & $1.6 \mathrm{~b}$ & $3.1 \mathrm{a}$ & $20 \mathrm{~b}$ \\
\hline Second & $30 \mathrm{~b}$ & $1.9 \mathrm{a}$ & $17 \mathrm{a}$ & $5.1 \mathrm{a}$ & $1.9 \mathrm{a}$ & $3.1 \mathrm{a}$ & $24 a$ \\
\hline \multicolumn{8}{|l|}{ ANOVA (F probability) } \\
\hline Blocks & 0.323 & 0.184 & 0.061 & 0.967 & 0.002 & 0.099 & 0.852 \\
\hline Treatments ( $\mathrm{T}$ ) & 0.083 & 0.189 & 0.100 & 0.834 & 0.970 & $<0.001$ & $<0.001$ \\
\hline Growing season (GS) & $<0.001$ & $<0.001$ & $<0.001$ & $<0.001$ & $<0.001$ & 0.721 & $<0.001$ \\
\hline $\mathrm{T} \times \mathrm{GS}$ & 0.933 & 0.999 & 0.922 & 0.905 & 0.722 & 0.506 & 0.092 \\
\hline Orthogonal contrast $(W G \times G)^{*}$ & 0.250 & 0.529 & 0.086 & 0.434 & 0.788 & $<0.001$ & 0.111 \\
\hline Orthogonal contrast $(\mathrm{WS} \times \mathrm{S})^{\S}$ & 0.087 & 0.117 & 0.124 & 0.247 & 0.286 & 0.538 & $<0.001$ \\
\hline
\end{tabular}

${ }^{\dagger}$ Values followed by the same letter within a column are not significantly different at $\mathrm{p} \leq 0.05$ according to the LSD test.

* Orthogonal contrast analysis between treatments with (G) and without (WG) phosphogypsum ( $\leq \leq 0.05)$.

$\S$ Orthogonal contrast analysis between treatments with (S) and without (WS) silicate ( $\mathrm{p} \leq 0.05)$.

previously (Table 5). Although phosphogypsum is also considered a source of $\mathrm{Ca}$, the effect of its individual application was lower compared with the other treatments, except control. However, at the second soil sampling, the action of phosphogypsum combined with lime and silicate led to higher base saturation values in all soil layers, indicating that the combination of these materials is a good alternative method by which to increase base saturation in soil subsurface layers through superficial application in an NT system. These results can be attributed to phosphogypsum, which promotes increased mobility of ionic bases throughout the soil profile (Peregrina et al., 2008; Caires et al., 2011). In a Brazilian Oxisol, Soratto and Crusciol (2008b) reported that the benefits of phosphogypsum for increasing base saturation only occurred in the soil surface layers (above a depth of $0.10 \mathrm{~m}$ ), but in this case, Ca sulphate was not combined with lime in the mixtures.
A possible deleterious effect of phosphogypsum on the leaching of basic cations, particularly losses of Mg and $\mathrm{K}$, was suggested by Alva and Gascho (1991). However, the downward movement of basic cations to subsurface soil layers is interesting in Oxisols and Ultisols, which are naturally nutrient poor, mainly in basic cations such as $\mathrm{Ca}^{2+}, \mathrm{Mg}^{2+}$ and $\mathrm{K}^{+}$. Therefore, the movement through the soil profile may increase the growth and development of the root system into the higher base-rich subsurface, with added benefits in crop systems. The results observed by Caires et al. (2011) considered the more probable positive effect of phosphogypsum because they reported low losses of exchangeable $\mathrm{K}$ and economic return as a result of increased cumulative grain yield of a crop rotation system over a period of four years.

The use of soil acidity amendments increased available $\mathrm{Si}$ in the shallow (0-0.05 and 0.05-0.10 $\mathrm{m})$ and deep soil layers $(0.10-0.20$ and

Table 7

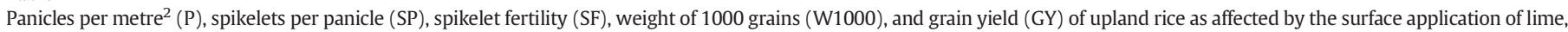
silicate, and phosphogypsum. ANOVA results are also shown.

\begin{tabular}{|c|c|c|c|c|c|}
\hline & $\mathrm{P}\left(\right.$ no. $\left.\mathrm{m}^{-2}\right)$ & SP (no. panicle ${ }^{-1}$ ) & $\mathrm{SF}(\%)$ & $\mathrm{W} 1000(\mathrm{~g})$ & GY $\left(\mathrm{kg} \mathrm{ha}^{-1}\right)$ \\
\hline \multicolumn{6}{|l|}{ Treatments } \\
\hline Control & $191 \mathrm{~d}^{\dagger}$ & $174 a$ & $79 a$ & $23.3 a$ & $3197 e$ \\
\hline Phosphogypsum & $198 \mathrm{~cd}$ & $179 a$ & $79 a$ & $23.5 \mathrm{a}$ & 3484de \\
\hline Lime & $200 c$ & $181 \mathrm{a}$ & $82 a$ & $23.8 \mathrm{a}$ & 3591cd \\
\hline Silicate & $223 a$ & $188 \mathrm{a}$ & $81 a$ & $24.1 \mathrm{a}$ & $4101 \mathrm{ab}$ \\
\hline Lime + Silicate $(\operatorname{mix})$ & $212 b$ & $183 a$ & $80 a$ & $23.9 a$ & $3909 b$ \\
\hline Lime + Phosphogypsum (mix) & $205 b c$ & $182 \mathrm{a}$ & $81 \mathrm{a}$ & $23.9 \mathrm{a}$ & $3801 b c$ \\
\hline Silicate + Phosphogypsum (mix) & $225 a$ & $191 \mathrm{a}$ & $83 a$ & $24.3 a$ & $4362 a$ \\
\hline Lime + Silicate + Phosphogypsum (mix) & $213 b$ & $185 a$ & $80 a$ & $24.0 \mathrm{a}$ & $3957 b$ \\
\hline \multicolumn{6}{|l|}{ Growing season } \\
\hline First & $206 a$ & $158 b$ & $79 b$ & $23.3 b$ & $3525 b$ \\
\hline Second & $211 a$ & $208 a$ & $83 a$ & $24.5 \mathrm{a}$ & $4075 a$ \\
\hline \multicolumn{6}{|l|}{ ANOVA (F probability) } \\
\hline Blocks & 0.785 & 0.147 & 0.445 & 0.222 & 0.615 \\
\hline Treatments $(\mathrm{T})$ & $<0.001$ & 0.696 & 0.642 & 0.564 & $<0.001$ \\
\hline Growing season (GS) & 0.127 & $<0.001$ & $<0.001$ & $<0.001$ & $<0.001$ \\
\hline $\mathrm{T} \times \mathrm{GS}$ & 0.930 & 0.997 & 0.230 & 0.999 & 0.246 \\
\hline Orthogonal contrast $(W G \times G)^{\ddagger}$ & 0.206 & 0.503 & 0.871 & 0.540 & 0.061 \\
\hline Orthogonal contrast $(\mathrm{WS} \times \mathrm{S})^{\S}$ & $<0.001$ & 0.107 & 0.456 & 0.071 & $<0.001$ \\
\hline
\end{tabular}

\footnotetext{
$\dagger$ Values followed by the same letter in the column are not significantly different at $\mathrm{p} \leq 0.05$ according to the LSD test.

* Orthogonal contrast analysis between treatments with $(G)$ and without $(W G)$ phosphogypsum ( $\mathrm{p} \leq 0.05)$.

$\S$ Orthogonal contrast analysis between treatments with $(S)$ and without (WS) silicate $(p \leq 0.05)$.
} 
$0.20-0.40 \mathrm{~m}$ ) three and 12 months after surface application, respectively (Table 5). The use of silicate has resulted in higher Si levels in Oxisols. This represents a good alternative for acid soils deficient in $\mathrm{Si}$, particularly Oxisols, which are typically low in Si (Korndörfer and Lepsch, 2001; Tavakkoli et al., 2011). Winslow et al. (1997) suggested sufficient Si values for rice soil, i.e., greater than $6 \mathrm{mg} \mathrm{kg}^{-1}$. It is important to emphasize that even though lime is not considered as a source of $\mathrm{Si}$, the application of Ca carbonate increased the available $\mathrm{Si}$ in the soil profile 12 months after application. This effect can be related to the formation of silica precipitates, commonly observed under acid conditions, which reduce plant Si availability. For this reason, the higher $\mathrm{pH}$ resulted in greater Si solubility in the soil (Oliveira et al., 2007).

\subsection{Leaf nutrients and Si concentrations}

The N, P, K, Ca, and Mg concentrations in the flag leaves were not affected by the application of amendments and phosphogypsum, applied individually or as a mixture (Table 6). Similar results were observed by Soratto and Crusciol (2008b), who reported that dolomite and phosphogypsum, applied separately, did not affect the foliar N, P, and $\mathrm{K}$ concentrations. However, these authors observed a linear effect of the dolomite rate on the $\mathrm{Ca}$ and $\mathrm{Mg}$ concentrations in upland rice leaves. In general, the absence of a similar effect in this study is assumed to be due to variations in dilution/concentration, which is a direct consequence of upland rice crop development.

The concentrations of Si and of all macronutrients, except $\mathrm{N}$ and $\mathrm{S}$, were higher in the second growing season than in the first, which demonstrates the positive effects of the treatments on the nutritional aspects of the crop (Table 6). The lower $\mathrm{N}$ concentration observed in the second growing season is probably related to some edaphoclimatic factor; however, it is important to emphasize that the N, P, K, Ca, and $\mathrm{Mg}$ concentrations in upland rice leaves in both growing seasons remained within a range considered adequate for rice (Cantarella et al., 1997).

The surface application of phosphogypsum (as a mixture and without amendments) only influenced the leaf $S$ concentration (Table 6). This is in accordance with the results observed by Soratto and Crusciol (2008b) and Crusciol et al. (2013), who reported that the use of S sources directly influences the uptake of S by upland rice. In both cases, the increase in the $\mathrm{S}$ concentrations in the flag leaves as a response to the elevated levels of sulphate in the soil was evident (Table 3). Despite the increase in leaf concentrations, all treatments, even those without soil acidity amendments, resulted in high $\mathrm{S}$ concentrations (1.4-3.0 $\mathrm{g} \mathrm{kg}^{-1}$ ) in the flag leaves according to Cantarella et al. (1997).

The Si concentration in the rice flag leaves was higher only when silicate was exclusively applied (Table 6 ), although the mixture with lime had potential for improving Si uptake by upland rice. The treatments that contained silicate led to higher Si concentrations in the leaves compared with the other treatments, as indicated by the orthogonal contrast analysis; this is a requirement for consideration as an important Si source (Oliveira et al., 2007). With respect to the effect of liming on Si solubilization, Castro and Crusciol (2013) verified that silicate is relatively more efficient than lime in increasing the Si content in upland rice flag leaves. Given the amount of Si extracted by the plant, which is several times higher than that of some essential macronutrients, such as P, K, Ca, Mg and S, using silicate as an important Si source is advantageous because rice is considered to be a $\mathrm{Si}$ accumulator (Yoshida et al., 1962; Guntzer et al., 2011). Seebold et al. (2000) reported that the foliar Si concentration of upland rice cultivars increased by 65 and $90 \%$ at Si application rates of 500 and $1000 \mathrm{~kg} \mathrm{ha}^{-1}$, respectively. In this study, the highest Si concentrations, i.e., 3.5 and $4.1 \mathrm{mg} \mathrm{kg}^{-1}$ for the Santa Rosa and La Libertad cultivars, respectively, resulted from a Si application of $1000 \mathrm{~kg} \mathrm{ha}^{-1}$

\subsection{Yield components and grain yield of upland rice}

The surface application of silicate and carbonate influenced the number of panicles per $\mathrm{m}^{2}$ (Table 7). Furthermore, the use of silicate, either exclusively or mixed with phosphogypsum, resulted in a higher number of panicles per $\mathrm{m}^{2}$ compared with the other treatments, which clearly shows the effect of Si on crop yield. Although less noticeable, lime application also favoured the formation of panicles, demonstrating that the use of soil acidity amendments benefits the reproductive development of the crop. However, little is known about the influence of $\mathrm{Si}$ on this yield component, and the results presented in the literature are contradictory. For example, Takahashi (1995) observed an increase in the number of panicles, whereas Mauad et al. (2003) did not detect positive effects.

None of the treatments affected the total number of spikelets per panicle, spikelet fertility, or the weight of 1000 grains (Table 7). Similarly, when assessing the effects of lime and phosphogypsum surface application on the yield components of traditional rice cultivars, Soratto et al. (2010) did not detect any effects of dolomite and phosphogypsum application on these variables. However, these authors noticed a dolomite and phosphogypsum interaction effect on the number of panicles per $\mathrm{m}^{2}$ and the number of spikelets per panicle. Increases in grain yield have been reported irrespective of the type or application method of soil acidity amendments.

The use of silicate as a soil acidity amendment is advantageous for improving upland rice grain yield, as confirmed by the orthogonal contrast analysis (Table 7). Increases in upland rice grain yield in response to Si have also been observed by Deren et al. (1994) and Liang et al. (1994) in traditional cultivars. Si has been hypothesized to be agronomically important for rice cultivation because of the range of benefits provided by this element. These benefits include increased growth and yield (Savant et al., 1997; Seebold et al., 2000), positive interactions with P- and N-based fertilizers (Sumner and Farina, 1986; Mauad et al., 2003; Lee and Kim, 2007), increased resistance to biotic (diseases and pests) and abiotic (drought, salinity, and lodging) stresses, and improved yield in problematic soils, such as acidic soils (Korndörfer and Lepsch, 2001).

The positive effect of silicate on panicle development and consequently grain yield may be related to the higher $\mathrm{Si}$ concentration in upland rice leaves observed in the second growing season (Table 7). Normally, Poaceae species adequately supplied with Si exhibit greater accumulation of $\mathrm{Si}$ in the leaf structures, which improves plant architecture and allows higher light absorption and synthesis of organic substances, with positive effects on plant productivity (Deren et al., 1994; Gao et al., 2004). Because of the intrinsic characteristics of these products, a delayed effect occurs when applying soil acidity amendments to improve soil chemical properties. Therefore, a higher grain yield was observed in the second growing season. Although cultivars of upland rice has been considered to be tolerant of soil acidity (Fageria et al., 2015), the development of modern cultivars, such as BRS Primavera, and our current results suggest that high acidity level reduces its productive potential.

\section{Conclusions}

The combination of soil acidity amendments (lime and silicate) and phosphogypsum improved the surface and subsurface soil chemical properties in an NT system. The surface application of phosphogypsum combined with lime and/or silicate improved the chemical properties of the deepest soil layers 12 months after surface application. The mixtures increased the concentrations of $\mathrm{K}, \mathrm{Ca}, \mathrm{Mg}, \mathrm{N}-\mathrm{NO}_{3}^{-}$, and $\mathrm{S}_{-} \mathrm{SO}_{4}^{2-}$ in the soil subsurface, which improved conditions for upland rice development.

The sulphur concentration in the flag leaves of upland rice was highest in response to phosphogypsum application, demonstrating this material as a source of $\mathrm{S}$ for upland rice crop production. 
The upland rice crop was influenced by the surface application of soil acidity amendments, irrespective of whether these products were combined with phosphogypsum, which resulted in positive effects on the number of panicles per $\mathrm{m}^{2}$ and, consequently, on the grain yield of upland rice.

\section{Acknowledgements}

The authors would like to thank the São Paulo Research Foundation (FAPESP, Proc. 2003/09914-3) and the Coordination for the Improvement of Higher Education Personnel (CAPES, PROAP - Program to Support Graduate) for financial support. In addition, the first, third, and fifth authors would like to thank the National Council for Scientific and Technological Development (CNPq) for an award for excellence in research.

\section{References}

Alcarde, J.A., Rodella, A.A., 2003. Quality and legislations of fertilizer and acidity correction sources. In: Curi, N., Marques, J.J., Guilherme, L.R.G., Lima, J.M., Lopes, A.S., Álvares, V.H. (Eds.), Topics in Soil Science. Sociedade Brasileira de Ciência do Solo, Viçosa, pp. 291-334 (in Portuguese).

Alva, A.K., Gascho, G.J., 1991. Differential leaching of cations and sulfate in gypsum amended soils. Commun. Soil Sci. Plant Anal. 22, 1195-1206.

Alva, A.K., Sumner, M.E., Noble, A.D., 1988. Alleviation of aluminum toxicity by phosphogypsum. Commun. Soil Sci. Plant Anal. 19, 385-403.

Bardsley, C.E., Lancaster, J.D., 1960. Determination of reserve sulfur and soluble sulfates in soils. Soil Sci. Soc. Am. J. 24, 265-268.

Bouman, B.A.M., Tuong, T.P., 2001. Field water management to save water and increase its productivity in irrigated lowland rice. Agric. Water Manag. 49, 11-30.

Caires, E.F., Alleoni, L.R.F., Cambri, M.A., Barth, G., 2005. Surface application of lime for crop grain production under a no-till system. Agron. J. 97, 791-798.

Caires, E.F., Barth, G., Garbuio, F.J., 2006. Lime application in the establishment of a no-till system for grain crop production in southern Brazil. Soil Tillage Res. 89, 3-12.

Caires, E.F., Garbuio, F.J., Churka, S., Barth, G., Corrêa, J.C.L., 2008a. Effects of soil acidity amelioration by surface liming on no-till corn, soybean, and wheat root growth and yield. Eur. J. Agron. 28, 57-64.

Caires, E.F., Garbuio, F.J., Churka, S., Joris, H.A.W., 2011. Use of gypsum for crop grain production under a subtropical no-till cropping system. Agron. J. 103, 1804-1814.

Caires, E.F., Pereira Filho, P.R.S., Zardo Filho, R., Feldhaus, I.C., 2008b. Soil acidity and aluminium toxicity as affected by surface liming and cover oat residues under a no-till system. Soil Use Manag. 24, 302-309.

Cantarella, H., van Raij, B., Camargo, C.E.O., 1997. Cereals. In: van Raij, B., Cantarella, H., Quaggio, J.A., Furlani, A.M.C. (Eds.), Recommendations for Fertilization and Liming in the State of São Paulo. IAC, Campinas, pp. 43-71.

Cantarella, H., van Raij, B., Quaggio, J.A., 1998. Soil and plant analyses for lime and fertilizer recommendations in Brazil. Commun. Soil Sci. Plant Anal. 29, 11-14.

Castro, G.S.A., Crusciol, C.A.C., 2013. Effects of superficial liming and silicate application on soil fertility and crop yield under rotation. Geoderma 195-196, 234-242.

Chung, J., Zasoski, R.J., 1993. Effect of high ammonium levels on nitrification, soil acidification, and exchangeable cation dynamic. Commun. Soil Sci. Plant Anal. 24, 17-18.

Churka Blum, S., Caires, E.F., Alleoni, L.R.F., 2013. Lime and phosphogypsum application and sulfate retention in subtropical soils under no-till system. J. Soil Sci. Plant Nutr. $13,279-300$.

Crusciol, C.A.C., Garcia, R.A., Castro, G.S.A., Rosolem, C.A., 2011. Nitrate role in basic cation leaching under no-till. Rev. Bras. Ciênc. Solo 35, 1975-1984.

Crusciol, C.A.C., Nascente, A.S., Soratto, R.P., Rosolem, C.A., 2013. Upland rice growth and mineral nutrition as affected by cultivars and sulfur. Soil Sci. Soc. Am. J. 77, 328-335.

Dancer, W.S., Peterson, L.A., Chesters, G., 1973. Ammonification and nitrification of $\mathrm{n}$ as influenced by soil pH and previous $n$ treatments. Soil Sci. Soc. Am. Proc. 37, 67-69.

Deren, C.W., Datnoff, L.E., Zinder, G.H., Martin, F.G., 1994. Silicon concentration, disease response and yield components of rice genotypes grown on flooded organic histosols. Crop Sci. 34, 733-737.

Elliott, C.L., Snyder, G.H., 1991. Autoclave-induced digestion for the colorimetric determination of silicon in rice straw. J. Agric. Food Chem. 39, 1118-1119.

Fageria, N.K., Morais, O.P., Carvalho, M.C.S., Colombari Filho, J.M., 2015. Upland rice genotype evaluations for acidity tolerance. Commun. Soil Sci. Plant Anal. 46, 1076-1096.

FAO, Food and Agriculture Organization of the United Nations, 2015. Conservation Agriculture Adoptions Worldwide. http://www.fao.org/ag/ca/6c.html (accessed 24.06.15).

Farina, M.P.W., Channon, P., Thibaud, G.R., 2000. A comparison of strategies for ameliorating subsoil acidity: I. Long-term growth effects. Soil Sci. Soc. Am. J. 64, 646-651.

Farooq, M., Kobayashi, N., Wahid, A., Ito, O., Basra, S.M.A., 2009. Strategies for producing more rice with less water. Adv. Agron. 101, 351-389.

Feng, L.P., Bouman, B.A.M., Tuong, T.P., Cabangon, R.J., Li, Y.L., Lu, G.A., Feng, Y.H., 2007. Exploring options to grow rice under water-short conditions in northern China using a modeling approach. I: field experiments and model evaluation. Agric. Water Manag. 88, 1-13.

Gao, X., Zou, C., Wang, L., Zhang, F., 2004. Silicon improves water use efficiency in maize plants. J. Plant Nutr. 27, 1457-1470.
Gozubuyuk, Z., Sahin, U., Ozturk, I., Celik, A., Adiguzel, M.C., 2014. Tillage effects on certain physical and hydraulic properties of a loamy soil under a crop rotation in a semi-arid region with a cool climate. Catena 118, 195-205.

Guntzer, F., Keller, C., Meunier, J., 2011. Benefits of plant silicon for crops: a review. Agron. Sustain. Dev. 32, 201-213.

Haynes, R.J., 1982. Effects of liming on phosphate availability in acid soils. Plant Soil 68, 289-308.

Ismail, H., Shamshuddin, J., Syed Omar, S.R., 1993. Alleviation of soil acidity in ultisol and oxisol for corn growth. Plant Soil 151, 55-65.

Ji, G.L., 1997. Electrostatic adsorption of anions. In: Yu, T.R. (Ed.), Chemistry of Variable Charge Soils. Oxford University, Oxford, pp. 112-139.

Keeney, D.R., Nelson, D.W., 1982. Nitrogen: inorganic forms. In: Page, A.L., Miller, R.H. Keeney, D.R. (Eds.), Methods of Soil Analysis. American Society of Agronomy, Madison, pp. 625-642.

Kilmer, V.J., 1965. Silicon. In: Black, C.A. (Ed.), Methods of Soil Analysis: Chemical and Microbiological Properties. American Society of Agronomy, Madison, pp. 959-962.

Kinjo, T., Pratt, P.F., 1971. Nitrate adsorption: ii. In competition with chloride, sulfate, and phosphate. Soil Sci. Soc. Am. Proc. 35, 725-728.

Korndörfer, G.H., Lepsch, I., 2001. Effect of silicon on plant growth and crop yield. In: Datnoff, L.E., Korndörfer, G.H.S. (Eds.), Silicon in agriculture (Studies in plant science) vol. 8. Elsevier, pp. 133-147.

Korndörfer, G.H., Coelho, N.M., Snyder, G.H., Mizutani, C.T., 1999. Evaluation of soil extractants for silicon availability in upland rice. Rev. Bras. Ciênc. Solo 23, 101-106 (in Portuguese with English abstract).

Kumar, V., Ladha, J.K., 2011. Direct seeding of rice: recent developments and future research needs. Adv. Agron. 111, 297-396.

Lee, Y.B., Kim, P.J., 2007. Reduction of phosphate adsorption by ion competition with silicate in soil. Korean J. Environ. Agric. 26, 286-293.

Liang, Y.C., Ma, T.S., Li, F.J., Feng, Y.J., 1994. Silicon availability and response of rice and wheat to silicon in calcareous soils. Commun. Soil Sci. Plant Anal. 25, 2285-2297.

Lindsay, W.L., 1979. Chemical Equilibria in Soils. John Wiley \& Sons, New York.

Malavolta, E., Vitti, G.C., Oliveira, S.A., 1997. Evaluation of Nutritional Status of Plants: Principles and Applications. Potafós, Piracicaba (in Portuguese).

Mauad, M., Crusciol, C.A.C., Grassi Filho, H., Corrêa, J.C., 2003. Nitrogen and silicon fertilization of upland rice. Sci. Agric. 60, 761-765.

McLean, E.O., 1982. Soil pH and Lime Requirement. In: Methods of Soil Analysis. Part 2 Chemical and Microbiological Properties. 2nd ed. American Society of Agronomy Inc. and Soil Science Society of America Inc., Madison, Wisconsin, USA.

Nascente, A.S., Crusciol, C.A.C., Cobucci, T., 2013. The no-tillage system and cover crops alternatives to increase upland rice yields. Eur. J. Agron. 45, 124-131.

Oates, K.M., Caldwell, A.G., 1985. Use of by-product gypsum to alleviate soil acidity. Soil Sci. Soc. Am. J. 49, 915-918.

O'Brien, L.O., Sumner, M.E., 1988. The effects of phosphogypsum on leachate and soil chemical composition. Commun. Soil Sci. Plant Anal. 19, 1319-1329.

Oliveira, E.L., Pavan, M.A., 1996. Control of soil acidity in no-tillage system for soybean production. Soil Tillage Res. 38, 47-57.

Oliveira, L.A., Korndörfer, G.H., Pereira, A.C., 2007. Silicon accumulation in rice in different rhizosphere pH conditions. Rev. Bras. Ciênc. Solo 31, 685-690 (in Portuguese with English abstract).

Pavan, M.A., Bingham, F.T., Pratt, P.F., 1984. Redistribution of exchangeable calcium, magnesium and aluminum following lime or gypsum applications to a Brazilian oxisol. Soil Sci. Soc. Am. J. 48, 33-38.

Peregrina, F.A., Arias, J.S., Fernandez, R.O., Fernandez, P.G., Serrano, R.E., 2006. Agronomic implications of the supply of lime and gypsum by-products to palexerults from western Spain. Soil Sci. 171, 65-81.

Peregrina, F.A., Mariscal, I., Ordónez, R., González, P., Terefe, T., Espejo, R., 2008. Agronomic implications of converter basic slag as a magnesium source on acid soils. Soil Sci. Soc. Am. J. 72, 402-411.

Prasad, R., 2011. Aerobic rice systems. Adv. Agron. 111, 207-236.

Qafoku, N.P., Sumner, M.E., 2001. Retention and transport of calcium nitrate in variable charge soils. Soil Sci. 166, 297-307.

Qu, Y., Ping, M., Hongliang, Z., Chen, Y., Gao, Y., Tian, Y., Wen, F., Li, Z., 2008. Mapping QTLs of root morphological traits at different growth stages in rice. Genetica 133, 187-200.

van Raij, B., Cantarella, H. Quaggio, J.A., Furlani, A.M.C., 1997. Recommendations for fertilization and liming in the State of São Paulo, Brazil. 2nd ed. IAC, Campinas (285 p. in Portuguese).

van Raij, B., Quaggio, J.A., Silva, N.M., 1986. Extraction of phosphorus, potassium, calcium, and magnesium from soils by an ion-exchange resin procedure. Commun. Soil Sci. Plant Anal. 17, 547-566.

Rãjan, S.S.S., Fox, R.L., 1975. Phosphate adsorption by soils: ii. Reactions in tropical acid soil. Soil sci. Soc. Am. Proc. 39, 846-851.

Reeve, N.G., Sumner, M.E., 1972. Amelioration of subsoil acidity in natal oxisols by leaching surface applied amendments. Agrochemophysica 4, 1-6.

Richards, L.A., 1941. Soil Moisture Tensiometer Materials and Construction. USDA-ARS, Washington.

Rutherford, P.M., Dudas, M.J., Samek, R.A., 1994. Environmental impacts of phosphogypsum. Sci. Total Environ. 149, 1-38

Santos, A.B., Stone, L.F., Vieira, N.R.A., 2006. The Rice Crop in Brazil. second ed. Embrapa Arroz e Feijão, Santo Antônio de Goiás.

Savant, N.K., Datnoff, L.E., Snyder, G.H., 1997. Depletion of plant-available silicon in soils: a possible cause of declining rice yields. Commun. Soil Sci. Plant Anal. 28, 1245-1252.

Seebold, K.W., Datnoff, L.E., Correa-Victoria, F.J., Kucharek, T.A., Snyder, G.H., 2000. Effect of silicon rate and host resistance on blast, scald, and yield of upland rice. Plant Dis. 84, 871-876.

Shainberg, I., Sumner, M.E., Miller, W.P., Farina, M.P.W., Pavan, M.A., Fey, M.V., 1989. Use of gypsum on soils: a review. Adv. Soil Sci. 9, 1-111. 
Sierra, J., Fontaine, S., Desfontaines, L., 2001. Factors controlling N mineralization, nitrification, and nitrogen losses in an oxisol amended with sewage sludge. Aust. J. Soil Res. 39, 519-534.

Smith, C.J., Peoples, M.B., Keerthisinghe, G., James, T.R., Garden, D.L., Tuomi, S.S., 1994 Effect of surface applications of lime, gypsum and phosphogypsum on the alleviating of surface and subsurface acidity in a soil under pasture. Aust. J. Soil Res. 32 $995-1008$.

Soratto, R.P., Crusciol, C.A.C., 2008a. Chemical soil attributes as affected by lime and phosphogypsum surface application in a recently established no-tillage system. Rev. Bras. Ciênc. Solo 32, 675-688 (in Portuguese with English abstract).

Soratto, R.P., Crusciol, C.A.C., 2008b. Dolomite and phosphogypsum surface application effects on annual crops nutrition and yield. Agron. J. 100, 261-270.

Soratto, R.P., Crusciol, C.A.C., Mello, F.F.C., 2010. Yield components of rice and bean cultivars as affected by lime and phosphogypsum applied in soil surface. Bragantia 69, 965-974 (in Portuguese with English abstract).

Stone, L.F., Moreira, J.A.A., Silva, S.C., 1986. Soil Water Tension and Rice Productivity EMBRAPA-CNPAF, Santo Antônio de Goiás.

Sumner, M.E., 1993. Gypsum and acid soils: the world scene. Adv. Agron. 51, 1-32.

Sumner, M.E., Farina, M.P.W., 1986. Phosphorus interactions with other nutrients and lime in field cropping systems. Adv. Soil Sci. 5, 201-236.
Sumner, M.E., Shahandeh, H., Bouton, J., Hammel, J., 1986. Amelioration of an acid soil profile through deep liming and surface application of gypsum. Soil Sci. Soc. Am. J. $50,1254-1258$

Takahashi, E., 1995. Uptake mode and physiological functions of silica. In: Matsuo, T., Kumazawa, K., Ishii, R., Ishihara, K., Hirata, H. (Eds.), Science of Rice Plant Physiology. Nobunkyo, Tokyo, pp. 420-433.

Tavakkoli, E., Graham, L., English, P., Guppy, C.N., 2011. Silicon nutrition of rice is affected by soil $\mathrm{pH}$, weathering and silicon fertilization. J. Plant Nutr. Soil Sci. 174, 437-446.

USDA, United States Department of Agriculture, 1999. Soil Taxonomy: a basic system of soil classification for making and interpreting soil surveys. 2nd ed. USDA, NRCS, Agriculture Handbook, Washington DC (<http://www.nrcs.usda.gov/Internet/FSE_ DOCUMENTS/nrcs142p2_051232.pdf> (07.07.15)).

USEPA, 1994. Land application of biosolids. A Guide to the Biosolids Risk Assessments for the EPA Part 503 Rule. Washington, DC. USA, USEPA.

Winslow, M.D., Okada, K., Correa-Victoria, F., 1997. Silicon deficiency and the adaptation of tropical rice ecotypes. Plant Soil 188, 239-248.

Yi, H., Xu, G., Cheng, H., Wang, J., Wan, Y., Chen, H., 2012. An overview of utilization of steel slag. Procedia Environ. Sci. 16, 791-801.

Yoshida, S., Ohnishi, Y., Kitagishi., K., 1962. Chemical forms, mobility and deposition of silicon in rice plant. Soil Sci. Plant Nutr. 8, 15-21. 